University at Buffalo School of Law

Digital Commons @ University at Buffalo School of Law

1983

\title{
Cases, Conflict, and Accommodation: Patterns of Legal Interaction in an American Community
}

David M. Engel

University at Buffalo School of Law

Follow this and additional works at: https://digitalcommons.law.buffalo.edu/journal_articles

Part of the Law Commons

\section{Recommended Citation}

David M. Engel, Cases, Conflict, and Accommodation: Patterns of Legal Interaction in an American Community, 8 Law \& Soc. Inquiry 803 (1983).

Available at: https://digitalcommons.law.buffalo.edu/journal_articles/494

This Article is brought to you for free and open access by the Faculty Scholarship at Digital Commons @ University at Buffalo School of Law. It has been accepted for inclusion in Journal Articles by an authorized administrator of Digital Commons @ University at Buffalo School of Law. For more information, please contact lawscholar@buffalo.edu. 


\section{Cases, Conflict, and Accommodation: Patterns of Legal Interaction in an American Community}

David M. Engel

This article provides an overview of an empirical study of a civil trial court and the environment of indigenous law and conflict resolution in which the court operates. The article combines an analysis of civil cases and litigants with an investigation of alternative nonjudicial approaches used by residents of the community. The first section of the article examines the emergence of legal conflicts from the fabric of social relationships in the community and compares cases and parties in the court with those that gravitate toward nonjudicial settings. The second section compares processes and outcomes available in the court with those that may be obtained nonjudicially. The article concludes that different categories of cases emerge from different kinds of social relationships and for this reason are associated with fundamentally dissimilar patterns of values, norms, procedures, and outcomes. It also emphasizes the benefits to be obtained from investigating the complex relationships and interchanges that link local level trial courts to their communities.

\section{INTRODUCTION}

The civil trial court of Sander County, Illinois, ${ }^{1}$ is a legal institution in which official law meets unofficial norms and processes, in which externally prescribed rules, definitions, legal categories, and procedures interact with indigenous community-based rules, values, procedures, and sanctions. The

David M. Engel is Associate Professor of Law and Adjunct Professor of Anthropology at the State University of New York, Buffalo, and Affiliated Scholar, American Bar Foundation. A.B. 1967, Harvard College; M.A., J.D. 1974, University of Michigan.

I am indebted to a number of people who contributed in important ways to this study. Space permits me to mention only a few: Felice Levine and Eric Steele for consultation and advice throughout the research project; Nancy Winship for her participation in the fieldwork and analysis; Kent Smith and Clara Carson for help and guidance in the statistics; Fred Konefsky and two anonymous but helpful reviewers for comments on the manuscript; the ABF publications department for editing and preparing the article; and Linda Kosinski for typing and retyping a number of earlier drafts. I am particularly grateful to the residents of "Sander County" who contributed their time and insights so generously.

This article is based on research supported by the National Science Foundation under Grant No. SOC 77-11654 and by the American Bar Foundation. Opinions, findings, and conclusions are, of course, those of the author and not of the supporting organizations.

1. "Sander County" is, of course, a pseudonym. The Sander County Court is a trial court of general jurisdiction handling not just civil cases but criminal cases as well. This study, however, focused on the civil case load. 
Sander County Court is not only a court of first instance in the official, multitiered system of state law but also a court of final review in the community's unofficial system of customary law and conflict resolution. The interaction of these two contrasting systems of obligation and social control determine the workings and case load of the court and explain when, how, and by whom the court is used and with what results.

Studies of civil trial courts have tended to neglect the ways in which formal legal processes and case loads are linked to indigenous social ordering and conflict resolution. Community-focused studies ${ }^{2}$ have demonstrated the rich array of informal norms and processes that act as alternatives to the formal legal system but have not usually related such findings to a systematic investigation of the activities of the local civil trial court. ${ }^{3}$ Institution-focused studies have suggested that formal processes and case loads are indeed affected by the social and cultural environment but have related external variables to judicial functions only at the most general levels (e.g., degree of socio-economic development, political culture, urbanization, and the like). ${ }^{4}$ What has been largely missing from the literature are studies that investigate patterns of civil litigation and judicial case processing in relation to indigenous patterns of social interaction, problem perception, and community life. Through the words and deeds of Sander County residents, this study explores how it is that cases in court emerge from the fabric of day-to-day social relationships and how, in turn, court processes affect perceptions of conflict and the emergence and channeling of "trouble cases" in the community. It compares normative systems and methods of social control in the court with those elsewhere in the community and integrates a primarily quantitative analysis of the court's civil docket with a qualitative exploration of the court's social environment.

The article has two major substantive sections. Section I deals with cases and parties. It concerns itself with the ways in which different kinds of cases crystallize (or fail to crystallize) out of the everyday lives of the people in the county. It addresses the various modes by which such cases, if they are in fact perceived as problems to be dealt with, come to be handled both judicially and nonjudicially. It examines the parties that tend to be involved in such matters and the role of courts and legal professionals. Beginning with an

2. E.g., Suzann R. Thomas-Buckle \& Leonard G. Buckle, Doing unto Others: Disputes and Dispute Processing in an Urban American Neighborhood, in Roman Tomasic \& Malcolm M. Feeley, eds., Neighborhood Justice: An Assessment of an Emerging Idea 78 (New York: Longman, 1982); Jack Ladinsky, Stewart Macaulay, \& Jill Anderson, The Milwaukee Dispute Mapping Project: A Preliminary Report, Disputes Processing Research Program Working Paper (University of Wisconsin Law School, 1979); Sally Engle Merry, Going to Court: Strategies of Dispute Management in an American Urban Neighborhood, 13 Law \& Soc'y Rev. 891 (1979).

3. Merry, supra note 2 , does attempt to relate litigation to disputing strategies at the neighborhood level. Other relationships between courts and conflict in a community are explored in Barbara Yngvesson, Court and Community in Two New England Towns (Paper delivered at the annual meeting of the Law and Society Association, Denver, June 3, 1983), and in Carol J. Greenhouse, Nature Is to Culture as Praying Is to Suing: Legal Pluralism in an American Suburb, $20 \mathrm{~J}$. Legal Pluralism 17 (1982).

4. See, e.g., Joel B. Grossman \& Austin Sarat, Litigation in the Federal Courts: A Comparative Perspective, 9 Law \& Soc'y Rev. 321 (1975); Lawrence M. Friedman \& Robert V. Percival, A Tale of Two Courts: Litigation in Alameda and San Benito Counties, 10 Law \& Soc'y Rev. 267 (1976); Wayne McIntosh, 150 Years of Litigation and Dispute Settlement: A Court Tale, 15 Law \& Soc'y Rev. 823 (1980-81). 
analysis of cases and parties in the civil docket of the county court, this section considers interactions and conflicts related to three particular substantive areas of law-torts, contracts, and family matters-in nonjudicial as well as judicial contexts.

Section II is concerned with processes and outcomes. Following the same format as section I, it examines the interrelationships between judicial and nonjudicial case processing and compares the outcomes available in different settings. It also addresses the effects of judicial processes and outcomes on nonjudicial norms and procedures in Sander County.

Together, the two sections provide a picture of a legal institution whose procedures and outcomes vary according to the underlying systems of social relationships in the community. Different kinds of social relationships are associated with differences in problem perception and definition, active or passive responses to problems, choices among nonjudicial and judicial alternatives, lawyer use or nonuse, case type classification, procedures applied, and outcomes obtained. Different kinds of social relationships are also associated with variations in the perception, interpretation, and invocation of formal legal doctrine by the parties involved. The social relationships from which civil cases emerge dictate the life history of the cases. In the etiology of civil litigation, to paraphrase Freud's famous dictum, relationship is destiny.

\section{A. Research Setting}

A word should be said about the research site and the fieldwork. Sander County is a rather small (population between 20,000 and 30,000 in the 1970 s), primarily rural county of Illinois. The county seat is the only significant population center, but there are several smaller towns. Although the county is primarily agricultural, the 15 years preceding this study saw an increasing amount of industrialization, with the establishment or expansion of several sizable plants employing significant numbers of industrial workers. Such activities have changed the employment patterns of many residents and have attracted workers of diverse backgrounds from outside the county as well. At the same time, there have been changes in the traditional farming occupations, with a gradual evolution away from smaller single-family farms toward larger units owned by distant corporate entities. With the building of new highways, in recent years Sander County has become more accessible to Illinois's large cities. Just as distances from farm to town within the county have "decreased," so have distances from the county itself to the major urban centers. And connections between the county and the outside world have also expanded through the impact of the mass media. Residents participate in the popular culture of the country as a whole in addition to the traditional life and values of their own community.

Although there is nothing aberrational or extraordinary about Sander County in comparison with other rural midwestern counties, it was not selected because it represents the "typical" rural American county (if such a county in fact exists). Rather, it was selected because its size, scale, and history provided an opportunity to study in a relatively manageable way the re- 
lationship between civil litigation and its social context. In Sander County it was possible to see with some clarity the outlines of a process that might have remained obscure in a larger and more complex social setting. Yet it seems likely that the basic relationships and interactions between judicial and nonjudicial systems uncovered here would be relevant to other environments as well. Although the details may vary from one setting to the next, the underlying structure of what we see here should be broadly applicable to the study of civil trial courts in their social contexts generally.

\section{B. Methodology}

The research on which this article is based was conducted in three phases. The first phase centered on a detailed examination of the civil docket of the local trial court. A probability sample of 373 cases over a two-year period (1975 and 1976) was drawn from the civil docket. The sample represented $20 \%$ of the entire civil case load for 1975 and $1976 .{ }^{5}$ All cases were read, noted, and analyzed by the author (the relatively small sample size permitted personal exposure to, interpretation of, and control over the data), and certain aspects of the cases that were particularly amenable to quantitative analysis were coded and analyzed. In connection with the docket study, I observed courtroom proceedings and engaged in extensive discussions with judges and court personnel. I also began to immerse myself in the life of the community.

The second phase of the research involved open-ended interviews with civil litigants whose names appeared in the docket sample. Most of the cases were selected at random from this sample, but they were supplemented by a few other cases from the sample that appeared particularly likely to inform the major themes of the study. Thus, the interview subsample was not representative of the entire civil docket in a strict statistical sense nor was it intended to be. Rather than a tightly controlled and restricted survey, the research effort at the interview stage consisted of an open investigation of leads and the pursuit of ideas as they emerged. The parties in 66 civil cases participated during this phase, and wherever possible, all named parties to each case were interviewed.

The third phase of the research involved open-ended and often lengthy discussions with a group of 71 "community observers"-individuals whose positions in the community made them familiar with the values and behavior of a variety of its groups and subgroups and who were therefore able to comment on formal and informal legal behavior in Sander County. Such individuals were selected on the basis of occupation, membership in particular organizations, political position, knowledge of their background or other relevant experiences, and references from other people who described them as especially insightful or knowledgeable about particular aspects of the local

5. From the civil cases filed over this two-year period, $20 \%$ were randomly selected from each of the 12 administrative categories of civil cases for 1975 and 1976. The administrative categories were: (1) law (claim over $\$ 15,000$ ), (2) law (claim $\$ 15,000$ or less), (3) chancery, (4) miscellaneous remedies, (5) eminent domain, (6) estates, (7) tax, (8) municipal corporations, (9) mental health, (10) divorce, (11) family, (12) small claims. 
society. The community observers included judges, lawyers, ministers, political officials, a realtor, high school teachers, farmers, an insurance company claims representative, a union steward, a management personnel representative, doctors, a barber, a hairdresser, school administrators, school board members, a newspaper reporter, public aid caseworkers, members of a rescue squad, a sheriff, youth workers, CETA officials, a funeral home director, the head of the council on aging, agricultural extension advisers, members of a Latino social organization, Grangers, and others.

In addition to a number of topics concerning Sander County itself, community observers were asked to comment on anonymous fact situations drawn from several civil cases that had been litigated and whose participants had been interviewed. These situations thus involved relationships or events from which conflict and litigation could (and did) arise. In their discussion of these anonymous fact situations, the community observers revealed how various systems for ordering relationships and resolving conflict in Sander County operated at the nonjudicial as well as the judicial level, and they provided numerous examples of nonlitigated relationships, problems, and conflicts that were similar to those that had become tort, contract, and family cases in the county court. Through these discussions, the significance of formal legal norms and procedures could be directly compared and contrasted with informal norms and procedures, and it became possible to understand in more general terms the role of the civil trial court in Sander County.

The three phases of the study were interrelated and cumulative. The first phase attempted to extract from the civil case files a sense of how the court was used and with what results. It permitted an examination of the kinds of cases and litigants with which the court dealt and the factors associated with different patterns of case processing and disposition. The second phase looked "behind the files" to the human experience of litigation. It examined how formal civil cases emerged from time to time out of the interpersonal dealings and relationships in Sander County, why events took the course they did in these cases, and what the ultimate meaning and effect of litigation was for those involved. The third phase attempted to place these questions in their broader social and cultural contexts. Together the three segments of the study provided a comprehensive, cross-cutting view of civil parties, cases, processes, and outcomes in Sander County.

\section{Social RELATIONShIPS AND THE EMERgENCE OF LEGAL CONFLICTS}

This section is concerned with how cases crystallize and parties emerge from the interactions, events, and relationships in Sander County. In particular, it focuses on the civil trial court in relation to various nonjudicial settings where comparable cases and parties might also appear. The relationship between judicial and nonjudicial settings in this regard is complex and variable. I shall suggest that one way to understand much of the variation is to sort the cases by subject matter. To illustrate this point, tort, contract, and family matters will be contrasted and compared. I will show that each of 
these three substantive categories of litigated cases was associated with different kinds and configurations of parties. I will suggest, further, that the underlying transactions or interactions from which these cases arose were fundamentally different for the three case types. Such relationships and transactions were associated with clearly distinguishable sets of norms and values in Sander County, and different kinds of responses were seen as appropriate in each instance.

Therefore, after a brief examination of cases and parties in the Sander County Court itself, I will examine each of the three case types-tort, contract and family-in its broader community setting. I will discuss the initial perception and definition of such cases or problems in their social context as well as the nonjudicial forums or resources that were used to handle them.

\section{A. Cases and Parties in the Court}

\section{Case Load}

Like most civil trial courts of general jurisdiction, the Sander County Court handled a broad spectrum of cases involving a wide variety of people. There are at least two ways of describing the case load of a trial court: by measuring the various components of its docket against one another or against some external standard, usually population. ${ }^{6}$

The first approach treats the different case types as slices of a single pie. In this form of analysis the various slices are compared in size to each other in order to arrive at a sense of the court's different functions and to compare the frequency with which these functions are performed. Figure 1 provides this kind of view of the Sander County Court for 1975 and 1976. It reveals, for example, that contract and family actions were far more numerous than other types of litigation, accounting for more than two-thirds of the civil cases filed during that period. Tort, probate, and property actions were far less frequent, and cases involving governmental matters and other miscellaneous topics were quite rare.

Figure 1 should not necessarily be interpreted to mean, of course, that the Sander County Court devoted most of its time and resources in civil matters to cases involving family and contract litigation. Many cases in these two categories were handled swiftly and routinely by court personnel. Family cases usually involved divorces ( $70.8 \%$ of all family cases) and contract cases usually involved collection actions ( $76.4 \%$ of all contract cases). Indeed, collection and divorce cases together constituted more than half $(51.5 \%)$ of the entire civil case load. Often collection and divorce cases were resolved in a

6. Population is sometimes described as a surrogate for the number of potentially litigable disputes in society, which can be compared to the number of disputes actually litigated in order to calculate a "litigation rate." There are, of course, serious conceptual problems associated with this approach. It is misleading to reify societal conflict in nonjudicial contexts as if it could be split into tangible, quantifiable units (disputes) that are treated as equivalent to litigated cases for purposes of statistical analysis. Further, even if the comparability of unlitigated disputes and litigated cases were not a problem, there is some question whether population is an appropriate surrogate to be used. See David M. Engel, Legal Pluralism in an American Community: Perspectives on a Civil Trial Court, 1980 A.B.F. Res. J. 425, 431-37; Richard Lempert, More Tales of Two Courts: Exploring Changes in the "Dispute Settlement Function" of Trial Courts, 13 Law \& Soc'y Rev. 91,96 (1978). 
matter of minutes with little active involvement by the judge, who played a managerial rather than a truly "adjudicatory" role in such matters. ${ }^{7}$ It should also be recognized that some functions of the Sander County Court were dominated by a small number of "repeat players"s and the volume of cases in these categories reflects the litigiousness of these few parties rather than the population as a whole. A collection agency and the local telephone company, for example, accounted for almost three-fourths of all collection cases brought in 1975 and 1976 . These two plaintiffs alone brought $20.8 \%$ of all civil cases filed during that period. A detailed breakdown of the civil docket by case type is presented in table 1 .

A second, and rather different, view of the civil case load is provided by measuring the volume of each case type against the population as a whole. This form of analysis permits at least crude comparisons between case loads of courts in different jurisdictions, since each case type is measured with re-

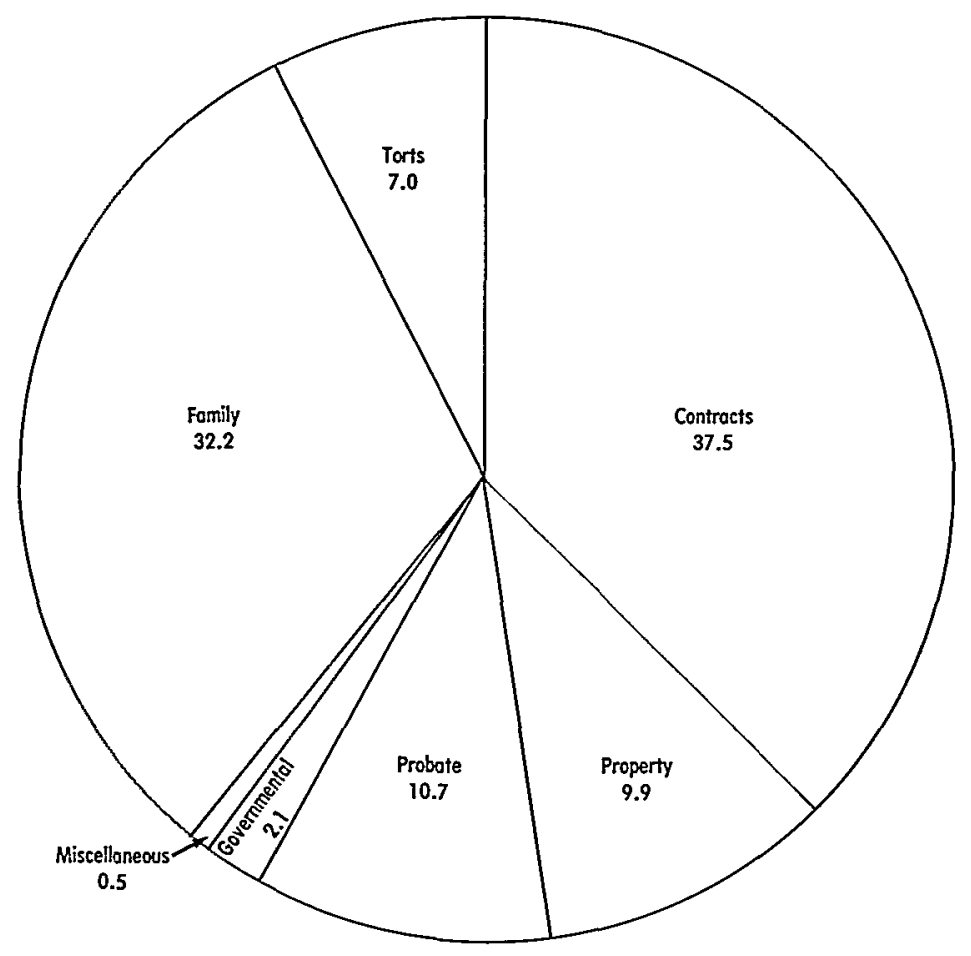

$N=373$

Fig. 1. Percentage of civil case load represented by seven basic case types

7. David M. Engel \& Eric H. Steele, Civil Cases and Society: Process and Order in the Civil Justice System, 1979 A.B.F. Res. J. 295, 312-14.

8. See Marc Galanter, Why the "Haves" Come Out Ahead: Speculations on the Limits of Legal Change, 9 Law \& Soc'y Rev. 95 (1974). 
spect to the population that might engage in such litigation rather than the frequency of other case types. The hazards of this form of case load analysis (and comparison) are both obvious and formidable and need not be discussed here. ${ }^{9}$ In Sander County, the problems are even more troubling because the population in 1975 and 1976 is not known. Census figures for 1970 are used for this analysis, but it is clear that the population as a whole had grown between 1970 and 1975 . Furthermore, informed local observers agreed that Latino residents had been seriously undercounted in the 1970 census and their numbers had increased sharply since 1970. Thus, in comparing case types to population, it should be remembered that the "litigation rates" are undoubtedly overstated because the population figures are too small.

Even when these facts are taken into consideration, however, litigation rates in Sander County still seem to be rather high, although this is more true for some case types than for others. In figure 2, litigation rates per 1,000 population in Sander County are compared with the rates reported in a wellknown study by Friedman and Percival of two California trial courts, one urban (Alameda County) and one rural (San Benito County). ${ }^{10}$

Comparisons with the California data provide at least a crude indication that the relative willingness or unwillingness of county residents to litigate varied greatly with the type of problem involved. The comparative figures provide some suggestion, for example, of a local reticence to bring tort-related problems to the county court-a subject to be explored later in more depth. In contract cases, on the other hand, the litigation rate greatly ex-

TABLE 1

Case Types and Percentage of Civil Docket, 1975-76

\begin{tabular}{|c|c|c|c|}
\hline Torts: & $\stackrel{\%}{\%=373)}$ & Family: & $\%$ \\
\hline Personal injury: & & Divorce.$\ldots \ldots \ldots \ldots \ldots \ldots$ & 22.8 \\
\hline automobile $\ldots \ldots \ldots \ldots \ldots \ldots$ & 2.4 & Support......... & 4.8 \\
\hline no automobile $\ldots \ldots \ldots \ldots$ & 1.6 & Hospitalization......... & 0.5 \\
\hline Property damage: & & Sealed $^{2} \ldots \ldots \ldots \ldots \ldots \ldots \ldots$ & 4.0 \\
\hline no automobile $\ldots \ldots \ldots \ldots \ldots$ & 2.7 & Probate: & \\
\hline & & Decedents estates .. & 5.9 \\
\hline Contracts: & & Inheritance tax ... & 2.7 \\
\hline Collection cases ... & 28.7 & Conservatorship.. & 1.6 \\
\hline Promissory notes..$\ldots \ldots \ldots$. & 2.4 & Guardianship.$\ldots \ldots \ldots \ldots \ldots \ldots$ & 0.5 \\
\hline Construction contracts $\ldots \ldots \ldots$ & 2.1 & Governmental: & \\
\hline Defective products or services . . & 0.8 & Tax $\ldots \ldots \ldots$ & 1.3 \\
\hline Miscellaneous contracts ........ & 1.6 & Education $\ldots \ldots \ldots \ldots \ldots \ldots$ & 0.5 \\
\hline Property: & & Zoning $\ldots \ldots \ldots, \ldots, \cdots, \cdots$ & \\
\hline $\begin{array}{l}\text { Landlord-tenant } \ldots \ldots \ldots \ldots \ldots \\
\text { Mortgage foreclosure.......... } \\
\text { Replevin .................... } \\
\text { Miscellaneous property . . }\end{array}$ & $\begin{array}{l}7.2 \\
1.3 \\
0.8 \\
0.5\end{array}$ & Miscellaneous................ & 0.5 \\
\hline
\end{tabular}

\footnotetext{
aSealed family cases: Adoption cases and petitions for marriage license orders were sealed and unavailable for inspection.
}

9. See Engel, supra note 6, at 434-35.

10. Friedman \& Percival, supra note 4 .. 
ceeded those of the two California counties (more than 5 times the rate of Alameda County and more than 8.5 times the rate of San Benito County). The disparity seems to be caused in part by jurisdictional differences, since the California Superior Court in 1970 had original jurisdiction in civil cases only when the amount in controversy was $\$ 5,000$ or more. ${ }^{11}$ The Sander County Court had no such jurisdictional floor, and many of its contract cases involved the collection of debts amounting to less than $\$ 5,000$. Though not as dramatically as for contract cases, the litigation rate in family cases also exceeded those of the two California counties, particularly Alameda County.

Thus, either approach to case load analysis provides rough preliminary indications that there were important differences among tort, contract, and family cases. Tort cases were litigated rather infrequently and contract cases rather frequently, while family cases occupied a middle position. These patterns emerge when case types are measured against one another or against the population of Sander County, and they also seem to hold up when rough comparisons are made with the two California courts studied by Friedman and Percival.
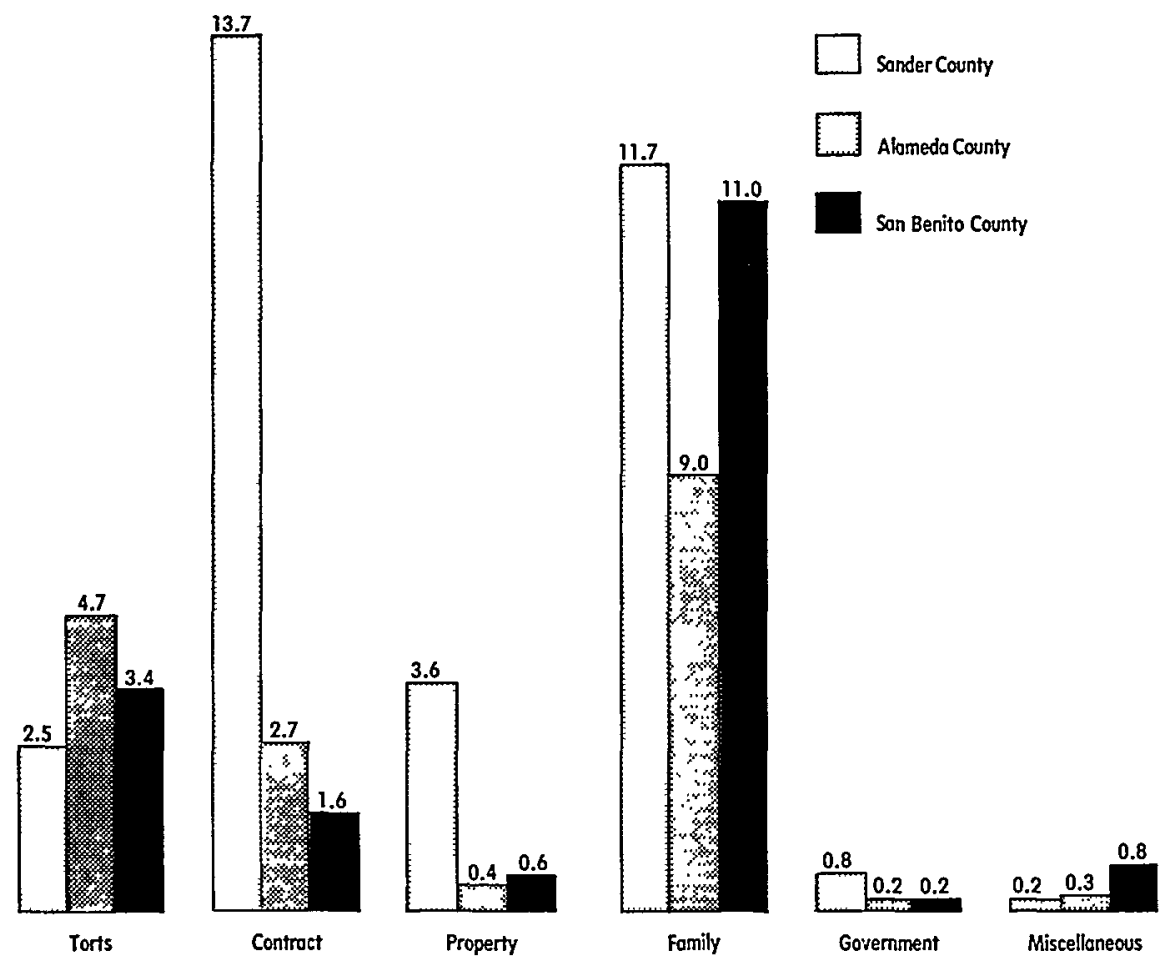

Fig. 2. Sander County litigation rates per 1,000 population (1975-76) compared to Alameda and San Benito counties (1970). (Sander County population figure is that provided by the 1972 County and City Data Book. Litigation rates for Alameda and San Benito counties are taken from Lempert, supra note 3. Only cases involving at least one named plaintiff and at least one named defendant are included.) 


\section{Parties}

Further differentiation among these three important categories of litigation appears when we shift the analysis from cases to parties and ask who it was that tended to bring litigation to the Sander County Court. Generally speaking, individual men, women, and children appeared far more often as civil litigants than did businesses or governmental units. Individuals were plaintiffs in $55.5 \%$ of the cases and defendants in $75.4 \%$. By contrast, businesses were plaintiffs in $37.8 \%$ of the cases and defendants in $8.5 \%$. Litigation involving governmental parties was far less frequent (plaintiffs in $2.2 \%$ of civil cases, defendants in $1.1 \%) .^{12}$

An analysis focusing only on individual and business litigants reveals that these two types of parties matched up quite differently in tort, contract, and family cases (fig. 3). ${ }^{13}$ Not surprisingly, in family cases only individuals were plaintiffs and defendants. ${ }^{14}$ More revealing, however, is the contrast between tort and contract cases. Tort plaintiffs were overwhelmingly individuals $(91.6 \%)$, and contract plaintiffs were overwhelmingly businesses $(86.5 \%)$. In the majority of tort cases $(58.3 \%)$, individual plaintiffs named other individuals as defendants, although a substantial minority of tort cases brought by individuals (33.3\%) involved business defendants. In the majority of contract cases (77.2\%), business plaintiffs sued individual defendants as opposed to business defendants $(9.3 \%)$. Contract litigation was almost always the arena in which business plaintiffs matched up against individual defendants. When this party configuration occurred, the odds were better than 99 to 1 that the case would be a contract rather than a tort action. In contrast, when the party configuration involved an individual suing an individual, the odds were only slightly over $50-50$ that the case would be a contract rather than a tort action.

The different party configurations for tort, contract, and family cases suggest that fundamentally different social interactions gave rise to these three types of cases. Tort actions in the Sander County Court tended to live up to their stereotyped reputation as wrongs involving strangers. Although some plaintiffs and defendants were acquainted before the alleged injury occurred, typically the relationship between the parties was created by the injury itself (e.g., the plaintiff was injured in a highway accident by an automo-

12. These figures do not include sealed family cases, for which no information was available. Since the only cases that were sealed involved either adoptions or petitions for marriage license orders, however, it is plausible to assume that the parties in such cases (which constituted $4.0 \%$ of the total civil docket) were individuals rather than businesses or governmental parties. Not included in the figures cited in the text are cases involving no defendants ( $10.7 \%$ of the civil cases in which parties were known), cases brought by the administrator or executor of an estate ( $0.5 \%$ of civil cases in which parties were known), and a single case in which a professional union was defendant $(0.3 \%$ of civil cases in which parties were known).

13. The significance levels given in figure 3 and in other figures are based on the chi-square test of independence. Since most of the data are at the nominal level of measurement, I have included the value of Cramer's V, which is a measure of association based on the chi-square statistic and can vary from 0 to $I$ in tables of all dimensions. In some figures the expected cell frequency, under the assumption that the rows and columns are independent of each other, is low for several cells. For these figures the significance level given is probably overly conservative; that is, it overstates the probability that the observed association could be produced by chance.

14. See infra fig. 3 . 
bile driven by the defendant, an industrial machine manufactured by the defendant injured the plaintiff who was using it, equipment owned and operated by the defendant in the course of its business activities injured an onlooker or passer-by).

Contract actions, on the other hand, typically grew out of prior transactions or agreements (e.g., the defendant bought retail goods from the plaintiff on credit, the plaintiff agreed to perform services for the defendant, the plaintiff engaged in construction work for the defendant pursuant to a contract they had agreed on). Litigation in contract cases did not arise in the technical sense from the initial interaction itself but from a hitch or problem that developed as the transaction unfolded. The parties were not total

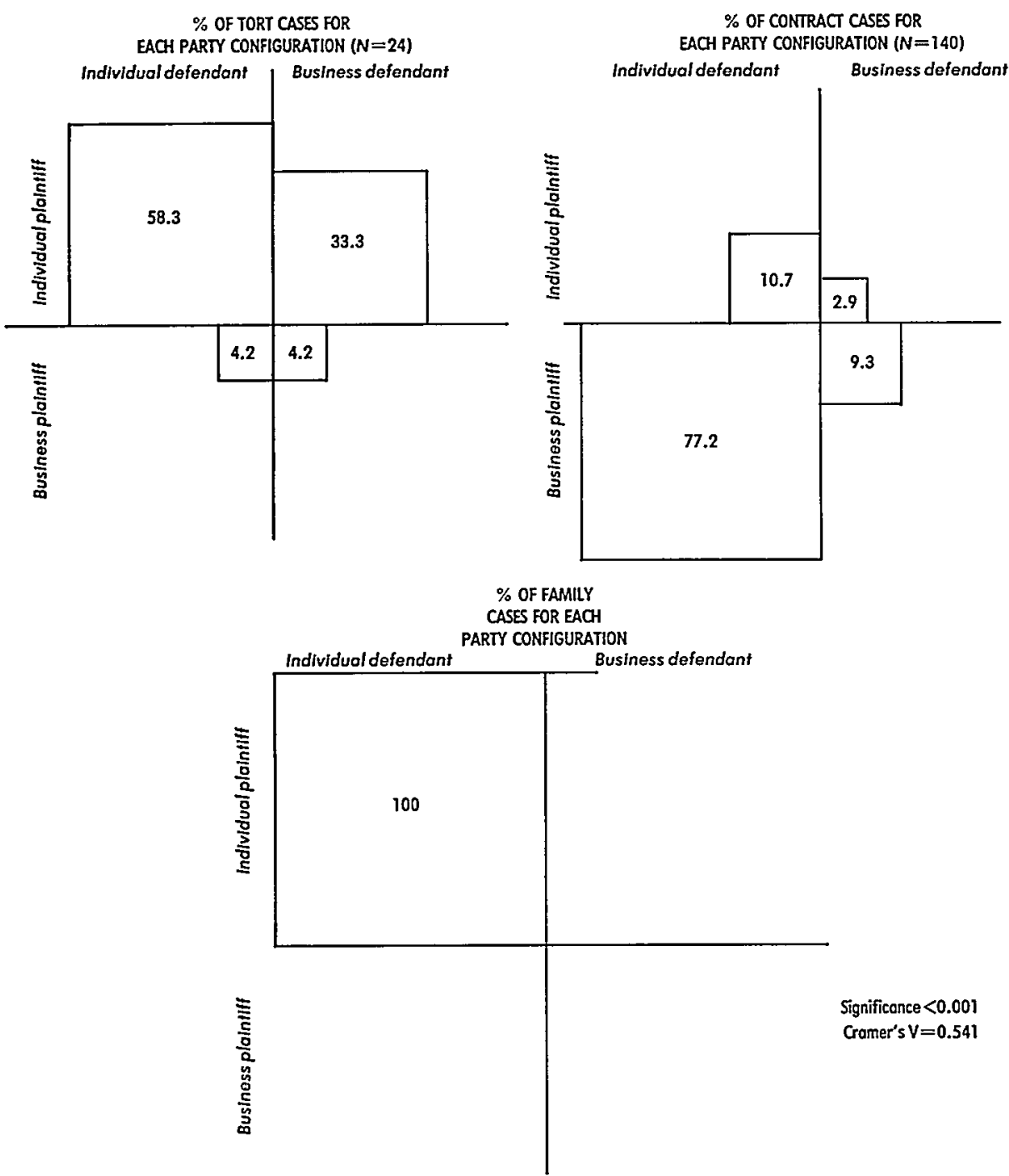

Fig. 3. Plaintiff-defendant configurations for each case type (two-party cases only) 
strangers. They had come together for some purpose before the problem manifested itself in a judicially cognizable form. ${ }^{15}$

In family cases, the litigants were typically related to each other in a different way. The parties were intimates; the relationship existed long before the particular problem giving rise to litigation. Most family cases grew out of the relationship of husband and wife. A broad spectrum of conflict and disagreement can occur within a marriage, including tortious wrongs and contractual breaches, but when such problems reached the court they invariably took the form of divorce actions by virtue of the underlying relationship between the parties. ${ }^{16}$

\section{Use of Lawyers}

Each of the three case types was, therefore, associated with a different pattern of social relationship and grew out of a different kind of social interaction. These different patterns were reflected to some extent in differences in lawyer use and nonuse in tort, contract, and family cases. That is, when cases did reach the court, they tended to involve lawyers in quite different ways depending upon the subject matter at issue. And, as we shall see in section II, outcomes in civil cases varied greatly according to the patterns of lawyer involvement.

In tort cases it was relatively common for both parties to be represented by counsel $(69.2 \%)$. In contract cases, on the other hand, it was relatively uncommon for both parties to be represented by counsel $(10.8 \%)$. Unrepresented defendants were the rule in contract cases $(86.4 \%)$ but were somewhat less prevalent in family cases $(55.8 \%)$ and were even less frequent in tort cases (26.9\%), perhaps because of the involvement of insurance companies' defense attorneys in tort litigation. Contract cases also differed from tort and family cases in the greater frequency with which plaintiffs appeared unrepresented by counsel ( $46.1 \%$ of contract cases), a phenomenon we shall consider later. Representation configurations for each of the three case types are displayed in figure 4.

Both plaintiffs and defendants who hired attorneys tended to select attorneys who lived in the county ( $67.2 \%$ of cases involving represented plaintiffs; $52.9 \%$ of cases involving represented defendants). This is not surprising, since most plaintiffs and defendants were themselves residents of the county (in $81.8 \%$ of the cases plaintiffs lived in the county; in $69.0 \%$ of the cases at least one of the defendants lived in the county). In tort cases, however, as opposed to contract and family cases, plaintiffs and defendants exhibited a distinct preference for attorneys located outside the county. Thus attorneys from outside the county were retained by plaintiffs in $87.5 \%$ of the tort cases involving represented plaintiffs and by defendants in $68.5 \%$ of the tort cases involving represented defendants. Whereas plaintiffs living outside the coun-

15. An important variation on this pattern involved cases brought by collection agencies, who often were strangers to the debtor. Nonetheless, even in cases of this kind, the litigation grew out of a hitch in a prior transaction or relationship, and the plaintiff who was a "stranger" stood in the shoes of a creditor who was already known to the defendant.

16. See infra discussion at 873. 
ty often hired Sander County attorneys when they brought an action in the Sander County Court for contract and family cases, they rarely did so when they brought tort actions. Sander County attorneys were clearly avoided in tort litigation. In part this may be explained by the participation of insurance companies and by the greater complexity of this kind of litigation as compared with the typical contract and divorce action brought in the county and the preference of tort litigants to hire attorneys who specialized in torts (most Sander County lawyers were "generalists"). In part, too, the explanation may lie in the fact that tort litigation involved a challenge to basic community norms in a way that contract and family litigation did not. But to understand this explanation, it is necessary to consider case types and parties in their social and cultural context, beyond the bare record provided by the case files.

$\%$ OF TORT CASES FOR

EACH REPRESENTATION CONFIGURATION $(\mathrm{N}=26)$

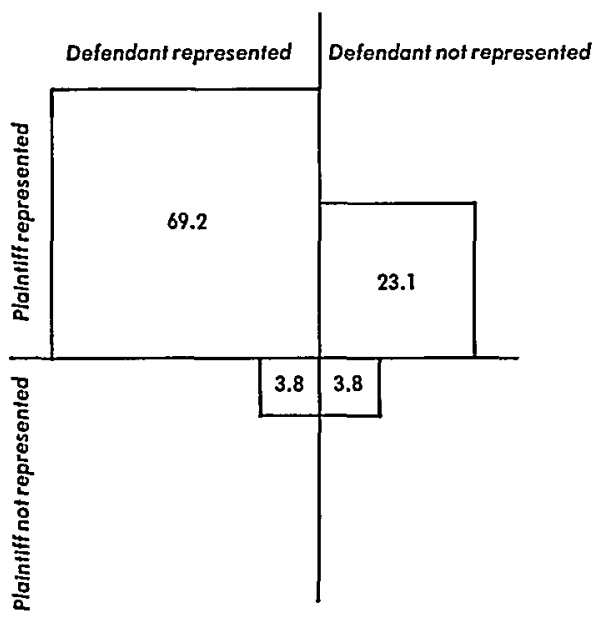

$\%$ OF CONTRACT CASES FOR EACH REPRESENTATION CONFIGURATION $(\mathrm{N}=139)$

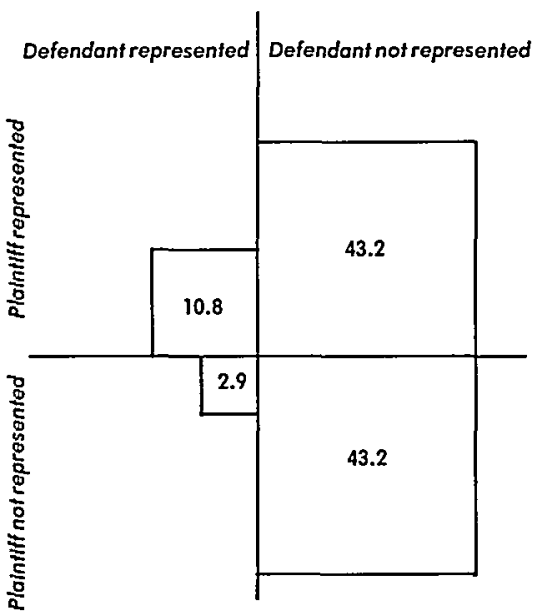

$\%$ OF FAMILY CASES FOR EACH

REPRESENTATION CONFIGURATION $(N=120)$

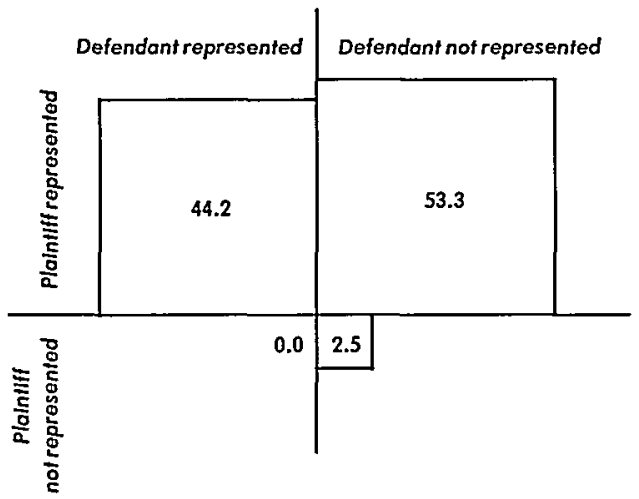

Fig. 4. Plaintiff and defendant representation configurations for each case type 


\section{B. Cases and Parties in the Community}

The Sander County Court represented only one of a number of normative systems in the community for ordering behavior, structuring relationships, and resolving conflict. Its civil case load contained the crystallization of "cases" out of the everyday mix of personal dealings, relationships, exchanges, and other events. The docket analysis suggested that the patterns of crystallization varied in certain important ways depending on which substantive area of the formal law was invoked, and investigation outside the court tended to confirm this. Tort cases involving injuries to persons or property emerged from a social milieu in which there was a strong inclination not to view such matters as appropriate for judicial (or even nonjudicial) processing. Contract cases often involving the collection of payments for goods and services emerged from a context strongly supportive of the enforcement of such obligations. And family cases, which usually involved divorces, emerged from a context of changing values and attitudes in which the clear trend was favorable to the dissolution of unhappy and unfulfilling marriages.

In this section, tort, contract, and family cases will be examined separately. In each instance, attention will be focused on two questions: What was the initial perception and definition of this kind of problem in Sander County? When the perception was one of injury requiring redress or conflict requiring resolution, how were cases channeled to particular forums and resources in Sander County, both judicial and nonjudicial? The answers to these questions will provide a broader view of cases and parties in the community as a whole.

\section{Torts $^{17}$}

a) Perception of injuries $\square \square$ Events that the formal legal system might define as tortious injuries were, at least in the traditional sectors of the community, not typically seen in such terms. Personal injuries, for example, were traditionally viewed as an ever present fact of life, something to be regretted but ultimately accepted. Farmers could recount many stories of exploding gas tanks, runaway tractors, workers getting caught in machinery, and the like, but such injuries were not perceived (by the injured person or by the narrator) as infringements of legal rights. They were simply things that happened to individuals who chose farming as a way of life. At best, one might hope that insurance would be available to help defray medical expenses. One did not, however, view such events in terms of a dispute or a conflict with someone else. In fact it was usually possible to imagine how greater care by the injured person might have prevented the injury. Even when this could not have been done, it was seen as highly inappropriate to attempt to "cash in" on one's own misfortunes by suing other individuals or the manufacturers or

17. For a detailed analysis of personal injury cases and community ideology in Sander County, see David M. Engel, The Oven Bird's Song: Insiders, Outsiders, and Personal Injuries in an American Community, 18 Law \& Soc'y Rev. (forthcoming 1984). 
sellers of faulty equipment. Money obtained by such means was viewed with distaste by people accustomed to thinking of money as the reward for hard work.

This basic attitude toward injuries appeared to have pervaded the thinking not only of farmers but of townspeople as well, although many of the newcomers to the community were described (even by themselves) as far more willing to seek compensation for injuries. Generally speaking, however, residents of Sander County viewed personal injuries in terms of fate rather than rights, and sometimes there was an element of pride in this attitude. All had read about enormous recoveries in tort cases litigated in big cities like Chicago and New York and were quick to point out that this could not happen in Sander County (as if to say that local life had not yet been corrupted by this form of urban decadence).

To some extent, too, it appeared that Sander County was still enough of a face-to-face society to provide informal kinds of relief that mitigated the otherwise stark consequences of incapacity due to physical injury in particular. For example, a farmer injured at harvest time was saved by his neighbors from economic disaster when they all joined in to pick his corn. This was described to me as typical behavior, something on which individuals could rely-presuming, of course, that they were sufficiently integrated into the local network of personal relationships. Given such systems of mutual support, the consequences of injuries for many well-established people in Sander County may have been less devastating than in other localities, and the necessity of characterizing the injury itself as a violation of one's rights may therefore have been less compelling.

b) The decision to litigate $\square \square$ Thus, when injuries occurred in Sander County there was a strong tendency not to perceive them in terms of violations of rights or in terms of conflict with another person. This tendency had important implications for the ways in which tort cases appeared and failed to appear in judicial and nonjudicial forums. People who did make the decision to litigate displayed a marked ambivalence about this course of action and about courts and legal professionals generally. They were not a conspicuously aggressive, rights-conscious group. Indeed they tended to be diffident, somewhat shy, people who, even after the passage of several years, were still uncertain how to interpret their injury and their experience with the legal system.

One soft-spoken grandmother, for example, had three fingers amputated while operating an allegedly defective industrial machine. In retrospect, she recognized that the machine was probably poorly designed and that her injury had had a major impact on her life, not only because of the trauma of the event itself but because her disability had limited the kinds of work she could perform and had resulted in her transfer to a lower-paying job in the plant. Still, she said: "I felt sorry for the machine company, too. They had a problem. It cost them a lot." She felt that the $\$ 7,000$ share of the settlement that she received was more than sufficient compensation: "I don't even think about it. As long as I'm happy and can live good, what more could I ask?" It is extremely doubtful that this woman would have considered litigation 
herself, and it appears that the suit was filed on the initiative of an insurance company exercising its right of subrogation. Even after the litigation had been concluded, it was still difficult for her to view the event itself in terms of legal conflict or a violation of rights.

Another tort plaintiff was a middle-aged man who had been disabled by a fall near a building where the allegedly negligent owner had allowed ice to accumulate on the sidewalk under a broken eaves spout. This man, too, had little relish for litigation: 'I'd banged, been in all kinds of scrapes and that, things, you know, I'd never given any thought of suing anybody. I don't think that's right either, actually." Nevertheless, his injury prevented him from working for a year and continued to limit his activities thereafter. For financial reasons, he felt compelled to bring a tort action. Ultimately his $\$ 100,000$ lawsuit was settled for $\$ 14,000$, an amount he considered far too small. In retrospect he viewed the litigation experience as "disgusting . . . a lot of wasted time." If he had it to do over again, he would "just forget it." Although somewhat more aggressive in his claim than the injured grandmother, his feelings about the appropriateness of litigation to resolve such matters were at best ambivalent, and the outcome of his lawsuit did little to change those feelings.

Other tort litigants expressed a similar ambivalence about the judicial system as an appropriate forum for considering their injuries. One woman's young daughter had been injured while playing on a trash dumpster behind a store. The injury involved damage to internal organs, and the girl's mother feared permanent harm might have been done. She was afraid that "maybe this would develop into something serious in later years that we might not be able to afford to pay for it." She finally brought a tort action alleging that the dumpster was negligently maintained and insufficiently protected against use by children. Even years later, her uncertainty about litigation as the proper course of action persisted:

I feel now that I shouldn't have done it, but then again when I think about it now that I think about it a second time, if it happened, if something like that should happen again, I would be terribly concerned, you know, about later complications.

The plaintiff in this last tort case was influenced in her retrospective view by a religious rebirth that had occurred after the litigation was concluded and that had enhanced her understanding of the entire matter:

I realize now that she really had no business being out there by that garbage can and she, if somebody had been watching her, you know, like I should have been, she wouldn't have gotten hurt.

Even so, like the man who had slipped on the ice, she felt that her settlement of $\$ 3,000$ was completely unsatisfactory, and she blamed her lawyer for failing to pursue the case strenuously enough. "Like I said, my attitude about everything is a lot different. Except lawyers, I still don't like them."

These tort plaintiffs, then, tended to internalize the community's widespread norms opposing the litigation of tort actions at the same time that 
they violated those norms by filing lawsuits. Their ambivalence toward judicial processing of such matters resulted from a persistent feeling that despite their decision to file a lawsuit, what had happened to them was inappropriate for litigation and perhaps should be accepted stoically without blaming and seeking compensation from someone else. The decision to litigate resulted in part from economic necessity, but it also appeared to be related to an incomplete integration into the local society and its ways. Individuals who were "outsiders" in terms of ethnicity, religion, politics, occupation, or socioeconomic status seemed less constrained by the pressure to conform to community norms than were individuals who were accepted into the community. When confronted with a "close" decision whether to sue or not, the outsiders were more inclined to go ahead.

c) Nonjudicial alternatives $\square \square$ The views expressed by many community observers tended to support this impression. All of them were asked to discuss a fact situation that was loosely based on the case brought by the mother of the injured girl. ${ }^{18}$ The most common response was that, judging from incidents with which they themselves were familiar, the parents of the injured child would not pursue the matter at all. In part, this was explained in terms of the local value system that considered litigation, or indeed any aggressive assertion of rights, to be an inappropriate reaction to such an accident. As one successful farmer observed:

The community as a whole would think that the individual is supposed to be smart enough to not get into these situations, and if they do get into the situation they should be able to generally get out of them without going to court. In other words, court would be the last resort, and the final thing would be many people would rather lose, . . . whatever value there was lost, whether it be the injury or the money or what, . . . than go to court.

In part, too, it was felt that the community still fostered close-knit interpersonal relationships, and to the extent these were available to serve as a "support system" for injured persons-in the psychological and material sense - responses framed in terms of the assertion of one's rights became less likely. Finally, and somewhat more ominously, two ministers suggested that parents involved in this kind of incident might refrain from pursuing the matter for a different reason-fear that publicizing the injury to their child might expose them to accusations of child abuse. This problem, according to

18. The wording of the fact situation presented to community observers, which was altered to protect the privacy and anonymity of the actual parties who participated in this study, was:

The Johnson's five-year-old daughter, Jane, was playing with some friends on the sidewalk in front of the Johnson's home. A beal construction company had dug a ditch beyond the sidewalk. There were no barricades or ropes around the ditch. Jane fell in and cut her arm. The injury required stitches and left a four-inch scar.

Supplementary questions probed (among other things) variability of problem perception and response to the problem among individuals of different income levels, Latinos versus Anglos, and long-time residents versus newcomers. Community observers were asked to respond to these various fact situations by citing specific events or cases in the community. 
the ministers, was much more widespread in the community than most people wanted to admit, and it silently shaped behavior in situations where children had suffered physical injuries of any kind.

Comments by the observers supported the conclusion that persons least integrated into the local society would be the ones most inclined to litigate when their child was injured in this way. They tended to distinguish among two groups in the local community: farmers and other long-time residents of the community, on the one hand, and newcomers, on the other. Farmers, it was agreed, would be the least likely to consider litigation or indeed any response aimed at recovering compensation from someone else. As one farmer put it: "Most of us would just think it's one of life's little accidents." Another farmer agreed: "Farm kids, you know, are quite prone to having accidents, and they're kind of used to it, I think. Usually just pick up and go on, and that's all." He went on to observe that even if some other party's negligence had clearly caused the injury, the parents of the child, if they were farmers, would be unlikely to raise the issue and would take it for granted that they (or the child) were ultimately responsible for the accident.

"Old-timers," townspeople as well as farmers, included people born and raised in the area and, if one took a very broad view of the matter, people who had moved to Sander County at an early age. Their values and behavior, it was agreed, closely resembled those of the farmers. A high-ranking school administrator, himself a newcomer to the community, observed that selfreliant behavior was favored among the long-time residents and that litigation by them was particularly unlikely. He referred to the traditional attitude of the local residents "whose macho says, take care of it yourself first." Many others, including a fundamentalist minister, agreed that the traditional values and social structure of the old-timers tended to inhibit aggressive or confrontational responses in situations of this kind:

The person that's lived here longer, you'd find it true that there would be more of a contentment, more of a stability. . . . I would have a tendency to believe that the stable person . . . he's the person that, well, "I can handle it myself."

By way of contrast, community observers almost unanimously agreed that newcomers to the community were far more likely to react to the injury as an infringement of rights rather than an ordinary part of life. Such reactions could take a variety of forms, including moving out of the community entirely. Others would stay and fight:

People that are from the area and brought up there . . . are a lot more reluctant to make waves than people that have moved from area to area that have been exposed to different cultures, you know, different environments. I think they would probably be more open-minded to the situation and take whatever action they felt deemed necessary. . . . With that mobility, I think, comes flexibility. And with that flexibility comes reaction, whether it's good or bad.

The absence of local "support systems" or alternative resources was cited as a reason that newcomers to the community might be more inclined to wage a dispute or even to bring a lawsuit. Newcomers to the community might be 
alienated from the traditional social order, hostile to it, or even unaware of the local antipathy to the assertion of claims in cases of injury. A union steward in a local industrial plant that hired many newcomers to the community had little doubt that most of his fellow workers would perceive such an incident in terms of a claim or a lawsuit and would feel few constraints about pursuing the matter as aggressively as possible.

Different groups of people in the community, then, tended to perceive and define injuries of this kind in quite different ways. There was a widespread tendency for many in the community, especially those adhering to traditional norms and values, to ignore or reject the possibilities for conflict latent in injuries to persons or property. The injury was simply not perceived in terms of one's relationship to the individual or organization that controlled, sold, or manufactured the instrumentality that caused the harm. That dimension of the event was suppressed, and the injury was seen solely in terms of the life, fate, and behavior of the injured person (and/or his or her parents, as in the case of the injured child). Thus, for many residents of Sander County (though not necessarily for newcomers to the community), a large number of occurrences that might have transformed themselves into formal tort actions were instead ignored or "lumped."

There were some nonjudicial resources or forums for injured persons to use when they wished to pursue such problems without necessarily engaging in litigation. Official complaint handlers were sometimes consulted when injuries of this kind occurred. The county health department was occasionally notified when children were injured by what their parents perceived as a public nuisance. The mayor or members of the city council were also called on in response to this kind of injury. Such action by the parents did not, of course, provide monetary compensation, but it did help to abate the public hazard, and this was seen as a legitimate concern for those who had suffered harm.

According to community observers, parents who were interested in obtaining compensation might contact the merchant or company directly, but this did not occur often or with great success. Liability insurance was also a factor in nonjudicial processing, but it did not seem to alter the basic reluctance of many Sander County residents to assert their claims. One social service worker commented that when her clients suffered what they perceived as a wrongful injury, she sometimes struggled with them to overcome their inhibitions against "picking a fight" with a fellow resident of Sander County. She tried to depersonalize the dispute in her clients' minds by convincing them that they were dealing not with the individual but with the individual's insurance company. Her record, she reported, was one of only limited success. A local insurance adjuster suggested, in discussing automobile-related injuries in particular, that even the assertion of a claim against an insurance company was not necessarily an impersonal or anonymous procedure in a community where so many people still knew one another:

R: As far as lawsuits that get filed on an automobile accident-or on any kind of claim for that matter-we have very few out of this office in comparison with our other county offices in the whole darn state. . . . 
People aren't so hotheaded, I guess, and they know each other. I think that knowing each other is the secret to the whole thing. In Chicago, all those people don't know the guy next door to them, much less the guy that they had the wreck with. And right here in town, if you don't know the people, you probably know their neighbor or some of their family or you can find out real quick who they are or where they are.

Q: Are those related, do you think? I mean, a person gets "hotheaded" when he doesn't know the other person?

R: I think so. I think they get scared. And then if somebody doesn't do something for them right now, as fast as they think they should, then they get mad. And once they're mad, then they are more inclined to decide that we are going to file suit, and we have a lawsuit here.

Q: You say you know most of the people you deal with?

R: Yes.

Q: They might not be so scared because you're a familiar person.

R: Right, they've found somebody they know. Right. . . . Even if we aren't insured with them, a lot of, I would say probably half, the people that I have a claim with right here in, people that live in town, if I don't know them I know some of their relatives or I knew them when they were in school. And they say, "Oh, that's right, you were in school with my brother Bill, yup." And there you go. They know who you are, and they don't get so excited.

Lawyers, too, could be used by persons who sought to obtain compensation for their injuries through nonjudicial means. Although this did sometimes occur, claimants tended to avoid local attorneys in such matters. In part, as the same insurance adjuster suggested, this was because local attorneys were not knowledgeable about matters involving insurance. In part, too, it was because local attorneys were viewed as members of the local established order and strongly influenced by its values and attitudes concerning tort claims. Since the claimants in such cases were typically outsiders or newcomers to the community, they believed the local bar was unreceptive to them and their claims and typically went to neighboring counties for legal assistance, whether for nonjudicial negotiation and settlement or for litigation. This lack of confidence in the local bar in such matters surely acted as yet another factor inhibiting the assertion of claims in any forum.

To summarize, the relative infrequency of tort litigation in the Sander County Court should be viewed in the context of a general reluctance on the part of the community to perceive injuries in terms of violations of rights and to define them as occasions for engaging in conflict with another. Although such values and attitudes were associated with long-time residents more than with newcomers to the community, other constraints deterred even the newcomers from engaging in the aggressive assertion of claims. Bilateral negotiations were not attractive in a community whose norms were not favorable to claims for compensation in injury cases. Nonjudicial resources were available but tended to emphasize the abatement of the hazard rather than the provision of compensation. Local lawyers were not knowledgeable about tort actions and, in any event, were believed to share the local antipathy to 
the assertion of tort claims. At all levels of the community, tort claims were discouraged and channeled toward nonconfrontational handling or the unilateral absorption of the harm by the injured party.

\section{Contracts}

a) Perceptions of contractual obligation and breach $\square \square$ Contract litigation presents a striking contrast to tort litigation in Sander County. Contrary to what we have seen with regard to tort litigation, norms inhibiting the assertion of contract-based claims were weak and norms supporting and reinforcing such claims were strong. Whereas local values tended to oppose strenuous insistence on compensation for tortious harms, they strongly favored aggressive efforts to ensure that promises would be kept and debts would be paid. Not only was litigation viewed as an appropriate means to enforce contractual obligations, but effective nonjudicial alternatives were also available and were freely invoked as the occasion required.

Local values and attitudes were conducive to initial perceptions of contractual breaches as serious wrongs and as appropriate occasions for pressing claims and, if necessary, engaging in conflict. Even the defendants in collection cases that reached the Sander County Court sometimes argued that their creditors' decision to litigate was entirely reasonable and appropriate:

When he got to the court, we knew we had to pay it because we owed the bill . . . . That court doesn't really have anything to do with it. If it's this person here whom the bill was owed to takes it to court, the court has to accept it. They don't have any choice. For them to have stood up in the court itself and said throw it out, how could they throw it out? The bill was honestly owed, and he had a right to collect it, so it was only a fair process.

Not all defendants in collection actions, of course, appreciated the rather routine judgments in favor of plaintiffs, which typically did not address the circumstances surrounding the creation of the obligation or the causes of the default. Nevertheless, there was a broad acceptance in Sander County of the basic premise that debts should be paid and that creditors were justified in taking necessary actions to secure payment even if it meant going to court. Even among the minority of defendants who explicitly adopted a catch-meif-you-can approach to financial obligations, when the game was finished there was recognition that the creditor was entitled to prevail. Seldom were questions raised concerning predatory sales practices, installment purchase plans, or even the legitimacy of a health care system that put doctors and hospitals in the position of trying to extract payments through the courts from individuals who were sometimes in desperate financial trouble. ${ }^{19}$

Statements of plaintiffs in such actions, not surprisingly, enthusiastically endorsed a strict conception of contractual obligations. As one man who ran his own small business explained:

19. The head of the local collection agency did, however, report that he sometimes encountered such questions in his own efforts to obtain payment of overdue accounts (e.g., from patients who questioned why they should pay an office visit fee to a doctor who did no more than refer them to another practitioner). 
I'm the type of a person that can get personally involved and a little hostile if somebody tries to put the screws to me. . . . I had it happen once for $\$ 5$ and I had it happen once for $\$ 12$. . . I explained to them carefully to please believe me that it wasn't the money because it would cost me more to collect it than it'd be worth, but because of the principle of it that I would definitely go to whatever means necessary moneywise or whatever to get it collected. And which I did.

Another plaintiff, the owner of a construction company located outside Sander County, sued a Sander County doctor for work performed on the latter's house. The defendant happened to be the third consecutive doctor who had failed to pay his bill in full (although the first in Sander County) and the plaintiff suspected that the doctor anticipated that a distant creditor would not be so active in collecting his debts. He was irritated with professional people who adopted this attitude and was inclined to take aggressive steps to collect such accounts, if only for his own psychological satisfaction. He had no question that his action was an appropriate response to the problem and he was gratified, after receiving a favorable judgment in court, that one of the doctor's neighbors patted the plaintiff on the back and said: "I'm glad you collected."

That the litigation of such claims was justified went almost without saying for many Sander County residents. Indeed, one business plaintiff noted that, because of the small size of the county, the local court tended to look out for local business plaintiffs and to help them collect their accounts as a matter of course, provided that the business people displayed a reasonable attitude and were not known to be shady or corrupt in their practices. Such a receptive attitude toward plaintiff's claims was, he felt, entirely appropriate.

b) Judicial and nonjudicial alternatives to contract problems $\square \square$ In contract cases, as in tort cases, the parties to formal judicial processing reflected the values and attitudes of the local community. Although the local legal culture tended to inhibit active responses to tortious wrongs, it supported and approved active responses to contractual breaches. Individuals were encouraged by the local normative system to perceive breaches in terms of important violations of legally protected interests and to take aggressive measures to protect such interests. The sharp contrast between tort and contract problems in this regard became evident when the community observers were asked to discuss a situation in which only $\$ 75$ of a $\$ 100$ bill for setting up a fence had been paid. ${ }^{20}$

The community observers described a set of values and attitudes operative

20. The wording of this fact situation was as follows:

Max hired Barry for $\$ 100$ to set up a fence around a building owned by Max. After Barry set up the fence, Max sent him a check for $\$ 75$. Barry wrote to Max and requested the remaining $\$ 25$, but Max has not paid him.

Supplementary questions probed variability of perception and response to the problem when services were performed for the local branch of a national soft drink company as contrasted with services performed for Max as an individual, Barry as a relatively wealthy individual versus Barry as a relatively poor individual, Barry as a man versus Barry as a woman, Barry as Anglo versus Barry as Latino, or Barry as long-time resident versus Barry as newcomer. As in the personal injury case, community observers were encouraged to respond to these various fact situations by describing and discussing comparable events or cases in the community. 
in this area of law that cut across the boundaries of different social groups in the county and included farmers, townspeople, and newcomers to the community. The consistent response by community observers was that such matters were regarded as extremely serious and were readily perceived in such terms by people who failed to receive payment for their services. In most sectors of the local society, incidents of this kind were acted on rather than ignored, and the consequences for the defaulting party could be serious. Some of the same farmers who had stated that reactions to personal injury cases were passive or restrained now insisted that the failure to pay a relatively small bill (some felt the amount at which action would be taken would be nearer $\$ 100$ than $\$ 25$ ) could cause "fireworks."

For cases of this kind, the Sander County Court was a popular, but by no means an exclusive, forum. Several nonjudicial alternatives were often considered, and unlike personal injury cases, few such cases were simply "Iumped." ${ }^{21}$ Personal contacts were often used in initial attempts to recover payment. That is, the individual who performed the service would persist in trying to make the other party pay her or his bill and would ask why the default had occurred. Violent self-help measures were sometimes used, and it was suggested in this particular fact situation that the fence might be destroyed or coercive efforts used to compel payment. Physicial fighting between the two parties was not unusual. Even in the absence of physical violence, the police were sometimes called on when such agreements were breached.

There was a broad consensus that the complainants in such situations, even if they took no other action, often let it be known throughout the community that the respondent had defaulted on the obligation. This was viewed as a very severe sanction in itself, since public opinion strongly condemned breaches of this kind. It was said that once it became known that individuals had failed to pay their bills, they could be cut off from the local system of reciprocities. No one would be willing to deal with them in comparable transactions or would trust them in agreements of any kind. Defaulters would be banished to a kind of exile within the community. Indeed, the very possibility that this form of sanction might be invoked was seen as so daunting that many of the community observers found it difficult to believe that such a contractual agreement would ever be breached in the manner described to them.

Although two-party negotiation was perhaps the most common approach to handling this kind of collection case, third parties could be invoked-and manipulated-at strategically important points in the negotiation. The interplay between two-party and three-party approaches was described at some length by representatives of the two most frequent civil litigants in Sander County-the telephone company and the local collection agency.

For these two business plaintiffs, litigation was simply another step in the sequence of events routinely associated with nonpayment of bills. Very often

21. The head of the local collection agency, however, maintained that lumping, or at least postponement of collection, was prevalent among local doctors. See infra discussion at $\mathbf{8 2 8}$. 
it was not even the final or ultimate step. Since default judgments for plaintiffs were entered in $46.1 \%$ of all collection cases, it was predictable that supplementary enforcement measures would be necessary in a large number of cases after a favorable judgment was obtained through adjudication on the merits. The final steps in the sequence, therefore, whether successful or not, often involved the garnishment of wages or other assets. Litigation in itself did not stand out as a dramatic or radical transformation of the dispute from one realm to another. It was an ordinary and rather efficient instrument available to businesses for conducting their day-to-day operations. And the simplified and inexpensive procedures of the small claims court in particular represented, in the words of the telephone company official, "a very, very effective collection tool."

Although this official did not view litigation as an extraordinary occurrence, neither did he consider the company highly aggressive or litigious by virtue of its frequent recourse to the Sander County Court. Collection operations at all stages were, he pointed out, regulated in great detail, in large part because of the telephone company's special status as a controlled monopoly:

That local businessman is not regulated as I am regulated. I have two or three books that thick with regulations that I have to live with, and I do not fight that regulation. I think that regulation is justified. I feel that consumer's interests should be looked after. I feel that the regulatory agency responsible for that has done a beautiful job.

Nonetheless, nonpayment of accounts could present particularly vexing problems for the telephone company. Nearly every household in the area had at least one account with the company. The scope of the company's operations was extremely large. Yet, asserted the same official, the risk of nonpayment was higher for the telephone company than it was for other utilities. When hard times came, the telephone was viewed by consumers as more expendable than water, electricity, or gas. With some inconvenience, an individual could go without a phone at home, but the household could not function without the other utilities. Therefore, if one bill had to go unpaid, it was most likely to be the telephone bill. Divorce and the increased mobility of local residents were also associated with the nonpayment of telephone bills and hence with the creation of this kind of frequently litigated case:

They're just leaving without paying the bill. They can be gone so fast you don't even know they're gone. They just totally abandon the service, leaving no address, no information, anything else.

In attempting to collect an overdue account, the telephone company typically would negotiate directly with the customer for 45 to 90 days. At the end of that initial period, the company would make a decision as to the likelihood of success if current efforts were continued. If the prospects for successful collection through direct contacts seemed doubtful, the matter would be referred to a collection agency. The collection agency would pursue nonjudicial procedures to a point, but if its attempts to collect over a "reasonable period of time" proved unsuccessful, the collection agency might recom- 
mend litigation in small claims court. The decision to litigate or not rested in each instance with the telephone company. If litigation was undertaken, the telephone company was the plaintiff of record, although the collection agency managed the procedure and supplied the attorney.

The telephone company official emphasized that litigation was often the consequence of a breakdown in two-party negotiations between the consumer and the company, and he blamed these breakdowns on failures of communication that were often unnecessary and avoidable:

It is important that the consumer talk to us. That is the biggest thing. . . . Basically there is a sense of distrust that was not created by the public, was not created by business, I don't know where it came from, but there is a sense of distrust that has grown that accounts for a lot of our hesitation, I believe, to talk. . . . If they would just come and say, "I just can't pay it. I can't pay it now. I'll pay it-"'and tell me when. But this is a very difficult emotion for any client or for any consumer to do that.

Failure of the debtor to communicate with the creditor was thought by company officials to create a situation calling for more aggressive collection measures, including litigation. Often major efforts to collect bills proved in retrospect to involve misunderstandings that could easily have been cleared up if better communications had existed. The telephone company official alluded to a recent case involving a man's nonpayment of a bill incurred during the period following his separation from his wife but prior to their divorce. The divorce decree specified that the husband was responsible for the telephone bill, but the man had failed to read the decree carefully and assumed that his responsibility ended when he left the house. Rather than discuss the matter with the telephone company, he unilaterally refused to pay the bill and waited until a lawsuit was filed. When the case came up for a hearing, he hired a lawyer and took a day off from work to defend himself in a case in which his position was clearly hopeless from the beginning:

The whole thing could have been avoided had we been able to communicate. But we made diligent efforts before ever referring the account and the agency retained that particular account for about, I think it was 14 months, and made every effort. . . . He ended up totally responsible. . . . The two of them, the two attorneys went to the bench and commonly agreed on the responsibility of the debt.

The director of the local collection agency (not the same agency that handled telephone company accounts) agreed that breakdown of communication between debtors and creditors was the key factor in the emergence of collection cases from the underlying strata of commercial transactions and relationships:

Anytime that you've got a person who is a debtor and does not pay his account, not only do you have somebody who is avoiding payment of a bill, and not only do you have the disgruntled creditor, but you've got a complete lack of communications. That's really what it boils down to. 
of the day-to-day interactions in Sander County, this collector cited carelessness as a primary cause for not paying bills. Since $50-60 \%$ of the accounts he handled involved medical bills, he cited the failure to obtain adequate insurance as a particularly frequent cause of many cases. Although medical bills formed a major part of his practice (often combined with florists' bills incurred by the same individuals or members of their family), this collector insisted that doctors locally handled many of their overdue accounts by a temporary or semipermanent form of lumping:

I'm aware of probably accounts that are here in the city that are $\$ 1,000$ or better and have been that way for the last eight to ten years. The same people, and they pay $\$ 10$ to $\$ 12, \$ 15$ a month, and sometimes nothing in a given month, but the next month they'll be back with $\$ 10$ or $\$ 12$. The woman who is handling that . . . on occasion has told me, and they will take it to the doctor and say to the doctor, "What should we do about this," and he'd say, "Don't worry about it. You know, they're good people, they've been patients here for years." So that's another element that the collector never gets involved with.

He admitted that in a process of this kind, based on long-standing relationships among local people, "a newcomer could have a little bit of a problem" but felt that on the whole the local medical profession would "go the extra ten yards for every single person."

Despite the apparent willingness of local doctors to carry debts for long periods of time, a great many medical bills as well as other types of bills came to the collector for action. His procedure for handling these bills was quite routine. He estimated that about $35-40 \%$ of the accounts he received were collected through ordinary procedures, while another $60 \%$ were not collected at all. Only about $3 \%$ were litigated, two-thirds of which resulted in payment of the debts. ${ }^{22}$ Generally speaking, he avoided litigation of debts less than $\$ 100$ but admitted that he would litigate "when it's just a deliberate type thing with an individual where I know that the individual's got the ability to pay the bill and it's just stubbornness on their part as to whether they won't." Even on the part of a professional collector, then, for whom the collection of debts was a routine business activity, a personal reaction to the perceived attitude of the debtor played some part in determining whether to adopt a moderate or an aggressive strategy:

Most people are honest, they want to pay their bills. Sometimes they have to be shown how to pay them. They have to know that not everybody's against them, that we are understanding, we will try to work with them. But on the other side of it, we're not going to be pushovers, we're not going to sit here and just, you know, take whatever they want to send. And there are a lot of people running around with that attitude, too. They seem to think that if they've got a $\$ 500$ medical bill, if they send $\$ 5$ a month, that does the job. . . . That's just, of course, not true.

22. The current director of the collection agency insisted that he was far less prone to litigate than the person who ran the agency during the period 1975-76, when the cases in the docket sample were filed. If the policy of the collection agency had changed in this respect, it could not be proven or disproven by the data gathered in this study. The former director of the collection agency was not available to be interviewed, but the current director was familiar with his policies and practices. 
For the collection agency, as for the telephone company, litigation did not represent a dramatic discontinuity in the procedures or relationships that existed outside of court. Litigation was simply "an effective tool" for carrying out everyday business practices, as von Clausewitz said of war and political relations, "by other means." Its primary value was to drive home to the debtor that the claim of the collector was a serious one and that the norms favoring payment had a solid legal as well as social (or moral) basis:

In many cases we are forced to go in and use the court system to make the person realize that the debt is going to be collected. In other words, they have not responded to anything we have done. We've sat here waiting for some sort of a gesture on their part, a good faith gesture that they would pay or even say, "We acknowledge we owe the bill." And for that reason, why with nothing like that done, why we go in and attempt to take the judgment.

Often the filing of the complaint alone was enough to drive the message home:

A lot of them . . . they pay at the time the complaint is filed because they realize that they really owe the debt. It's a legitimate debt and if they go before a judge, unless they want to lie, they're not going to get out of saying they owe the debt.

For the business plaintiff (and it should be remembered that $86.5 \%$ of all contract cases were brought by businesses), contract litigation was a simple extension of everyday commercial activities, unremarkable yet effective in many cases. As the local collector put it, litigation of such cases "gives a little more semblance of order." "Order" is a particularly apt term in both of its senses. The normative order of the community as well as the legal system itself strongly supported the business plaintiffs' attempts to collect their debts. This made it relatively easy for business plaintiffs to obtain another kind of "order"-a judicial decree supporting their claims and permitting them to use supplementary enforcement procedures to collect their debts if necessary. Not only were businesses and individuals encouraged to regard contractual breaches in terms of significant normative violations, but they had at their disposal several highly effective procedures-both judicial and nonjudicial-for seeking redress. The landscape of alternatives was as rich and various for contract matters as it was barren for tort matters.

\section{Family}

a) Problem perception and court use in family conflicts $\square \square$ Cases and parties in family matters differed in many ways from both tort and contract matters. Most obvious, of course, is the nature of the underlying relationship. Divorce cases, which will be the primary focus of this discussion, involved two individuals who had lived together as intimates. Litigation, when it occurred, had as its ostensible purpose the termination of the relationship itself rather than the provision of compensation or other remedies available to tort and contract plaintiffs.

Divorce cases, as has been seen, were litigated rather often, both in rela- 
tion to other case types and in relation to the per capita rates reported by Friedman and Percival in their California trial court study. The residents viewed the local divorce rate with some uneasiness, and many of them believed that the chances for a successful marriage were now only one in two. Local people felt that the norms concerning marriage were in the process of rapid change, and divorce was not only more common but more widely accepted than it had ever been before. This was an area in which threshhold perceptions of grievances had once been suppressed and the assertion of claims discouraged. And although changes over time could not be measured directly by the data collected in this study, there were strong indications that the litigation of marital problems had once been viewed in highly negative terms (like tort litigation) but was now accepted as almost commonplace (like contract litigation).

Discussion with some litigants in divorce cases made it clear, however, that no matter how frequent such litigation may have become in Sander County, it could often leave the participants in considerable psychological conflict and pain. In this sense it differed sharply from contract litigation. Some litigants agonized for long periods of time whether to file for divorce. One woman, who had been married 12 years and had two children, filed for divorce only after an extended separation. Her lawyer initially sensed that she was unready for divorce and urged her merely to obtain a temporary support decree. Only later, when she realized that her husband was never coming back and that other problems were likely to develop if the marriage was not dissolved, was she willing to initiate the divorce action. In contrast, another divorce plaintiff filed suit less than four months after her second marriage. She had recognized almost immediately that the marriage was a mistake, primarily because of her husband's complicated relationship with his former wife, and she feared that the longer she allowed the marriage to continue the more traumatic it would become for her and for her young son from a prior marriage. She described herself as a person who could not stand indecision, who would prefer to make a definitive decision promptly, even if it was wrong, than to allow a situation to drag on. Nonetheless, she admitted that the process took a severe emotional toll on her son and put her through "a personal hell," making her "a basket case." A third couple filed for divorce after being married 13 months. The woman, at the time of filing, was only 17 years old and found married life as a high school student boring and confining. Her husband, who was 24 , wanted to try to work things out but agreed to a divorce when he learned that she had not gone home to her parents as they had agreed but was living with another man. The divorce, as painful as it was, liberated both of them from a marriage they later recognized to have been a mistake.

Divorce litigation, then, while following routinized patterns worked out by lawyers and judges over the years, usually was a complicated, difficult, and enormously important matter for the individuals involved. The litigation of such a case was an emotionally taxing process. Yet none of the litigants expressed the kinds of inhibitions about litigation that were seen among the tort litigants. None sensed that he or she was violating community norms by filing 
for divorce or that the process was socially stigmatizing. It is true that for some individuals who were well known in the community, it could be embarrassing to expose this aspect of their private lives to public scrutiny:

I work with a lot of attorneys here in town; and I got up to the courtroom and they said, "Oh, are you here with so and so (somebody I'd been talking to)?" "No, I'm here for my divorce." And I found that, to me, that was very embarrassing. . . . And then the children, it was rather embarrassing on them because it's always in the paper. It isn't anymore, I believe, but at that time it was in the paper when anybody got a divorce. . . . My phone was unlisted, but I know I've had friends that the day their divorce was in the paper they've had obscene phone calls that night.

This kind of embarrassment differed, however, from the more profound sense of social alienation experienced by tort litigants. While the parties to a divorce may have wished that the process could have been accomplished with greater privacy, none doubted the propriety of using the courts for such a purpose. In this, they reflected the prevailing values and attitudes of the community as a whole.

The overwhelming impression gained from discussion with observers throughout Sander County was that couples unhappy with their marriage were less likely than ever before to accept the situation passively. They increasingly viewed a satisfactory marital relationship as a matter of right and were willing to take steps to resolve their unhappiness, even if it meant engaging in overt conflict with their spouse or ultimately filing for divorce. As one minister observed:

[The] commitment for marriage today is very low. . . . It used to be that divorce was looked upon, in the community as well as in the church, it was looked upon as a sin or as a disgrace. But it's no longer looked upon that way. The attitude of people today, if it don't work out then so what. And I think that people would tend to, especially today, are using counselors less and divorce courts more.

Although virtually all community observers agreed on this trend in Sander County as a whole, some noted that there were subgroups in which disapproval of divorce remained strong. In the growing Latino population, for example, it was felt that the traditional culture and the Catholic religion made divorce unacceptable. As one Latino observer said: "In the Spanish community and the Spanish culture, when you get married, that's forever." Another Latino observer commented that when a marital relationship began to go sour, she had often seen that the man would seek extramarital relationships with other women, while his wife would be left to endure stoically without any fulfilling relationship at all:

She would be the, how would you say, the offended wife. And therefore she had to stand up, if she wanted her son to have his father, she would have to put up with it and think maybe even the parents would tell her, "You have to tolerate this sort of thing. Your father went through the same thing and look, he's still with me, so therefore you have to put up with it. Try and make it, try and get along with him." 
Some observers believed that the traditional values opposing divorce lingered longer in rural than in urban areas. This was because the extended family remained a more prominent feature of rural society, and it was felt that the extended family placed a greater emphasis on continuity of relationships and also provided a structure by which disapproving attitudes could be expressed with some effectiveness to couples contemplating a divorce. The rural-urban distinction in values was suggested tentatively, however, and was rejected by other community observers. An agricultural extension adviser who was a long-time resident of Sander County, for example, pointed out that there was considerable intermarriage between farm and city people, which resulted in a blurring of many of the differences between rural and urban values. Furthermore, rural and urban children now had much more contact with one another as they grew up, and thus the development of their value systems was pretty much the same:

You don't have your country schools sitting out here anymore. So these kids have grew up together. . . . You don't have this fence, separation, between the urban and rural people, and you've got your city girls taking baton lessons and tapping lessons the same as you do the farm kids. . . . And so I don't think you're going to see, or I don't think you can see this big differential in a lot of values or how they would approach things just because they live on a farm or if they live on Main Street.

Because it was recognized that values and attitudes concerning divorce had changed radically in Sander County over time, some observers believed that the older generation was more likely to adhere to traditional values opposing divorce while the younger generation was more likely to reflect the newer and more accepting values. In part, this was seen as a matter of different generations adhering to different social norms. But it was also suggested that young married couples would be less concerned about stigmatization simply because their social standing, their place in the community, was less firmly established than that of an older married couple. The younger couple would feel less constrained and freer to act because they had less to lose, both materially and socially. There was some agreement among observers that members of the community applied a double standard to unhappy couples depending on their age. Thus, one minister had seen the children of such couples, who would accept the idea of divorce for themselves and their contemporaries, oppose the idea of divorce for their parents:

They would intercede, say, "Hey mom and dad, you can't get split at this age. It would just be a scandal." And I think they expect, all those young people, not expect, but they would anticipate younger people to dissolve more freely than an older couple. It becomes more of a shock in this community when older people do dissolve after 20,30 years of marriage.

An individual who had been active working with the elderly in Sander County, however, emphasized that changing attitudes toward divorce had indeed had a profound impact on the older generation, just as they had on the younger generation. Thus, regardless of the expectations of their children or other members of the community, senior citizens did not necessarily 
adhere to traditional attitudes opposing divorce and were much readier to consider dissolution of unhappy marriages than the outside world may have realized:

I don't think that the generalities of society are a lot different for seniors . . . . Seniors are just grown-up people. Well, they are. Things that happen to us don't happen any differently to them. They may be more used to George because they've been married to him for 44 years, but the things that annoyed them when they were married ten years probably still annoy them. Including sexual problems. They talk about those things, too.

She firmly believed that seniors in Sander County had "looked at the fashion" concerning the acceptability of divorce with just as much interest as had the rest of the local population.

b) Nonjudicial alternatives $\square \square$ In exploring Sander County for nonjudicial settings where cases of this kind might be handled, I was struck by the dearth of forums between self-contained two-party procedures and formal litigation. Third parties who could serve as nonjudicial alternatives to the civil trial court tended to be ineffective or seldom consulted by couples with marital problems. During the fieldwork for this study, community observers were asked to comment on a fairly typical situation involving a couple who had married young, had a small child, and had come to feel that they did not love each other anymore, although neither felt the other had done anything wrong. The overwhelming response of the community observers was that couples like this in Sander County filed for divorces. Intermediate resources were seldom mentioned and were, according to almost all the observers, rarely used.

Some of the old-timers mentioned friends or relatives in similar situations in the past who had simply lumped it. One of them moved to the downstairs bedroom and the couple continued to share a home on this basis for years. Yet, as we have seen, all community observers agreed that this was no longer the norm. The following statement by an older woman, contrasting her own tolerance of an often unhappy marriage with the more permissive modern attitudes toward divorce, reflects both envy and disapproval of couples who do not have to lump it as she did:

I would have left my husband dozens of times if I had a means of support. . . . I think maybe lots of girls used to feel that way. But now it seems as if kids strike out now with actually nothing. I mean, they don't worry about where their next meal is coming from like we used to. I don't think that we have given young people the sense of responsibility that they need so that they can cope with these difficulties that they have, and it's easier to walk away from them because they don't need security. There are jobs readily available; they can make it. When I was a girl, there was not a job waiting.

Lumping had become far less frequent. Often, without consulting any counselor or other third party, the couple simply separated, either by agreement or through the unilateral action of one of the spouses. Such arrangements could continue for a long time if neither party filed for divorce and would thereby act as an informal alternative to the formal judicial divorce 
procedure. A separation could also be used as an interim measure, leading either to a court-sanctioned divorce or to a reconciliation. As a union official observed concerning his fellow industrial workers:

In some cases they would just split for a year or so. . . . A lot of people feel that if they get away from the wife or husband, whatever, for a year that makes the heart grow fonder. They say absence makes the heart grow fonder, but in some cases it does work that way. I've seen several cases at work where they'll split for, oh, anywheres from a month to six months, a year, and get back together, and it does seem to be working all right.

When third parties were brought into situations involving unhappy marriages, they were most likely to be friends or neighbors rather than professional counselors. One woman, who had served as an informal adviser for several of her friends when they had marital problems, observed:

I'll tell you who they will talk to and pay more attention to than the ones that can give them any help, is they will talk to their friends, their neighbor, or whatever, and that's who they'll go to. . . . And if that person says to them, "Well now, don't get excited," then maybe they won't. And if the person says, "Well, that darn so-and-so" and on and on and eggs them on, then they'll come to blows that much faster, probably.

While some observers felt that there was often a reluctance to involve friends and neighbors with such intimate problems - and a corresponding reluctance on the part of the third party to become involved-this type of third party was thought to be used more widely than any other except courts and lawyers. Indeed, one divorce litigant who had moved to Sander County from Detroit felt that in the smaller town it was especially likely that friends and neighbors would become involved because social networks were closer and people were more concerned about one another. If the same problem had occurred in Detroit, 'I don't think anybody would have cared. Because it's a big metropolis. It's your problem, you go settle it." But in Sander County he was gratified to find that his friends rallied around him to help bring him back together with his wife and when that proved impossible provided him with moral support to proceed with the divorce.

Other third party resources were only occasionally sought out and used by couples in unhappy marriages. A home economics extension service adviser, for example, might be asked by a farm wife what she should do when her husband walked out on her. A doctor might be approached by an unhappy patient for some tranquilizers and some informal marital counseling to go with them. Many observers, however, emphasized that there was a deepseated aversion to seeking professional counseling. This was explained in terms of a "rugged individualism" that pervaded local attitudes, an unwillingness to admit that there were problems and that help was needed to handle them. Traditionally "everybody took care of their own problems." There was a kind of pride in this approach to difficulties, and there was also a sense that professional counselors were a luxury that only the rich could afford. Few such resources were available in the county, and to get counseling people would have to go to neighboring counties. Some of the divorce litigants 
stated in their interviews that they had tried counseling, although usually for just one or two sessions, and the lawyer who handled most of the divorce cases said that he routinely sent his clients to a marital counselor. The use of professional counseling as a resource for unhappily married couples, however, was likely to come so late and was likely to be approached with such suspicion and reluctance that it seldom proved effective.

Local ministers also observed, with some despair, that they were used as a resource for marital difficulties less often than they might have wished and usually at such a late stage that there was little they could do to preserve the relationship:

Maybe they'll talk to friends. They'll have a, like the woman might have a close girlfriend and she'd talk to her. But only when divorce, something legal is imminent would they tend to come to see me about it. Because basically they don't seek counseling as such. It's only, it's kind of a last ditch effort. . . . That's the sad thing about it. They would tend to drift until it reaches a point where they feel they have nothing more invested in the relationship. And then they would take other steps. They tend not to come, at least for professional help, until it appears too late.

This unhappy assessment was shared by many other ministers as well. In fact, some of them had focused their attentions on premarital counseling for this very reason. Though pastors were not much involved with marital problems once they existed, many did try to help prospective couples anticipate and prevent problems before they occurred. Indeed, often by discussing some of the difficulties and responsibilities of marriage with couples who were not yet married, they tried to deter those whose marriages would inevitably have ended unhappily. Furthermore, at least one minister urged couples at this early stage that if problems developed they should consult him before seeing a lawyer:

When I marry a couple anymore I say, "Don't see a lawyer before you see me." I say, "I have a responsibility in performing this marriage and you have a responsibility to see me before you break up." I say, "If you didn't go see a lawyer to get married, so before you break up you come and see me." I said, "Then if we think we can't save it, I'll go with you to the lawyer." And I've done that several times.

The preceding overview of nonjudicial settings in which marital problems were handled in Sander County suggests that although the landscape of informal resource utilization was not totally barren, there were few prominent features between the unhappy household and the door to the lawyer's office. In this sense, divorce cases were more like tort than contract cases but without the initial inhibitions against problem perception and the assertion of claims that characterized the tort field. Of course once divorce cases reached the lawyers' offices, the lawyers too could attempt to act as nonjudicial resources for disaffected couples, and occasionally they succeeded in reconciling them. In general, however, lawyers who attempted conciliation faced the same obstacles as the ministers and other counselors-the relationship was already in such an advanced stage of deterioration that there was little 
for them to do besides setting in motion the legal machinery to ratify the decision already reached by the couple.

As this discussion suggests, there were some important distinctions between family matters and the other two substantive topics (torts and contracts) that we have already considered. The dominant cultural values concerning torts and contracts, despite recent changes in the local society, continued to disfavor claims based on tortious injuries almost as strongly as they favored claims based on contractual breaches. Family matters (and I have focused only on divorce in this discussion) suggested a broad and sweeping shift in Sander County norms from a negative attitude comparable to that associated with torts to a permissive, even positive, attitude comparable to that associated with contracts. This is not to say that unhappy marriages were now viewed, like contractual breaches, in terms of a reprehensible wrong or an infringement of rights. On the contrary, the growing acceptability of divorce litigation appeared to be linked to a changed perception of the concept of fault in the breakdown of a marriage. Unlike the formal law of Illinois, which then still required allegations of fault, it was felt that partners in an unhappy marriage should be permitted by law to go their own ways without necessarily portraying one as a blameworthy wrongdoer and the other as an innocent victim. ${ }^{23}$

The judicial and nonjudicial handling of family matters in Sander County reflected many of these same distinctions. Whereas lumping once had predominated as a method of dealing with such matters it was no longer used by most persons and groups in the county. In a marriage that had truly broken down, separation of the parties was very common, whether judicially sanctioned or not, and divorce was quite likely to follow. Couples with marital problems found few acceptable intermediate forums for their problems, but this fact did not cause married couples to bottle up their difficulties entirely. When the marriage became unlivable, it was not stigmatizing or shameful to file for divorce-or at least the stigma and shame had diminished in the dominant culture to the point where they no longer deterred couples in such situations from bringing divorce actions. The nature of the parties in such litigation (individual vs. individual) and the nature of their underlying relationship (intimate members of the same household as opposed to a commercial relationship or a relationship based on an accidental injury) appeared to have a strong bearing on the kinds of settings that were viewed as appropriate or inappropriate for handling family cases. As we shall see in the next section, these distinctions also led to important differences in the processing and disposition of tort, contract, and family cases.

\section{The Social Context of Case Handing and Disposition}

In section I, I discussed the emergence of cases in various nonjudicial and judicial settings in Sander County. I suggested that the underlying relationships between different kinds of people and organizations in the community 
correlated with the substantive categories of these cases as well as with the types of forums toward which they gravitated. In this section I shall explore the nature of processing and the outcomes in cases once they have emerged in particular settings in the community. As before, I shall suggest that the nature of the underlying relationship between the parties is crucial in determining how the cases are handled and resolved. In this section, as in section I, I shall begin with an examination of tort, contract, and family cases in the local trial court before expanding the discussion to include a variety of forums and resources in the community as a whole.

\section{A. Process and Outcome in the Court}

\section{Process}

The Sander County Court, like other trial courts that have been the subject of empirical study, defied stereotypical images of courts that emphasize trials and appeals. ${ }^{24}$ Among the civil cases completely processed (i.e., not pending) in which the nature of processing could be ascertained from the file, more than nine out of ten were resolved without trial. Jury trials were extremely rare $(0.6 \%$ of all civil cases) and appeals were even more rare $(0.5 \%$ of civil cases). No cases in the sample were appealed beyond the first level of review-the district appellate court.

In Sander County, as elsewhere, idealized conceptions of the civil trial court as a forum for full adversarial confrontation bore little relationship to the realities of the judicial process. The processes by which civil cases typically were handled did not involve trial and adjudication by judge or jury but negotiation, settlement, total capitulation, or even nonparticipation by one or both parties after a complaint had been filed. Figure 5 shows that this generalization holds true for the three primary case types, although the percentage of cases processed without trial varied from $80.0 \%$ (torts) to $96.2 \%$ (family).
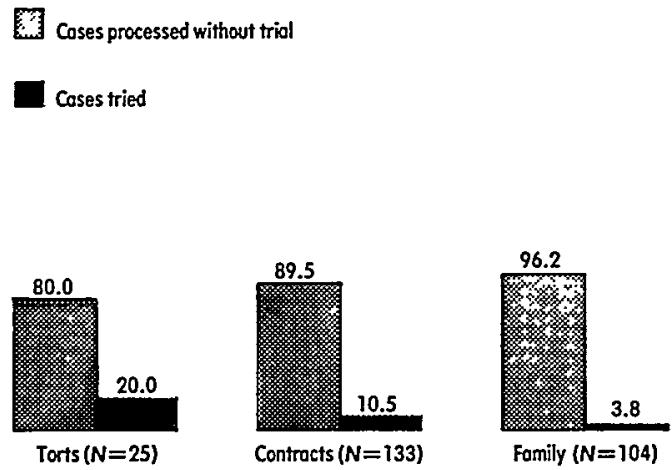

Significonce $=0.022$

Cromer's $V=0.170$

Fig. 5. Percentage of cases processed with and without trials for each case type 
In order to analyze the factors associated with variations in this basic pattern of civil case processing, I shall discuss process in the court in terms of four alternative modes of handling cases. The first mode is "one-party nonadversarial" processing, which involves unilateral, uncontested petitions to the court (such as petitions involved in probating an estate). The second is "two-party nonadversarial" processing, which includes cases in which there were potential adversaries aligned against one another yet no formal contested proceedings occurred and the case was handled by the court in a nonconfrontational manner. The third mode is called, for want of a better term, "delayed muscle," and it includes cases in which the initial disposition was a simple, nonadversarial matter but the postadjudication enforcement was coercive and potentially confrontational, involving the attachment of assets or the garnishment of wages. The final mode of processing is the full-fledged "adjudicated contest" in which the trial court engaged in a more extensive exercise of its formal procedures. As table 2 suggests, this last form of case processing was the least common, while nonadversarial approaches were by far the most frequent.

Although the general tendency was to avoid formal adjudication, different types of civil cases tended to gravitate in distinctive patterns toward different modes of processing. "One-party nonadversarial" processing turned out to be the exclusive domain of probate cases and was not used for any other type of case in the sample for which the mode of processing was known. ${ }^{23}$ The other three modes of processing were used somewhat differently in cases involving torts, contracts, and family matters (fig. 6).

Figure 6 points once again to fundamental differences among the three primary case types. Tort cases displayed the highest proportion of adjudicated contests, the lowest proportion of delayed muscle, and a relatively high proportion of two-party nonadversarial processing. By contrast, contract cases involved the highest proportion of delayed muscle and the lowest proportion of two-party nonadversarial procedures. The family case type stood midway between these two in the use of delayed muscle but was lowest in the proportion of adjudicated contests and highest in two-party nonadversarial processing.

TABLE 2

Case Processing in the Court

\begin{tabular}{|c|c|}
\hline & $\begin{array}{c}\% \text { of All } \\
\text { Civil Cases } \\
(N=373)\end{array}$ \\
\hline Adjudicated contest . . . . . . . . . & 8.8 \\
\hline Delayed muscle .............. & 14.5 \\
\hline Two-party nonadversarial ........ & 56.8 \\
\hline One-party nonadversarial ....... & 10.7 \\
\hline Unknown $^{\mathrm{a}} \ldots \ldots \ldots \ldots \ldots \ldots$ & 9.1 \\
\hline
\end{tabular}

ancludes sealed family cases, pending cases, and others in which the nature of processing could not be determined from the file.

25. Many of the sealed cases, which included adoptions and petitions for marriage license orders, may have been handled in this manner, too. 
Thus, while two-party nonadversarial case processing was the dominant mode for all three case types, significant variation between case types was nonetheless present. Tort cases tended more markedly toward adversarial adjudicative procedures, while contract cases tended to emphasize supplementary enforcement procedures as their second most frequent mode of processing. Family cases showed only slight use of either of these two secondary processes and emphasized two-party nonadversarial procedures even more exclusively than did tort and contract cases. Despite a common preference for nonadjudicative procedures, the three case types are associated with three rather different litigation profiles. Apparently the judicial process was used differently in tort, contract, and family cases. Such a conclusion is not surprising in light of the earlier finding that different kinds of parties, relationships, and social interactions are associated with each of the three basic case types. Indeed, it is possible to state with some specificity the relationship between process and particular variables associated with the parties and the cases themselves. In the analysis that follows, case processing in the Sander County Court is examined in relation to three variables that appear to be of particular importance: nature of party, representation by counsel, and amount sought.

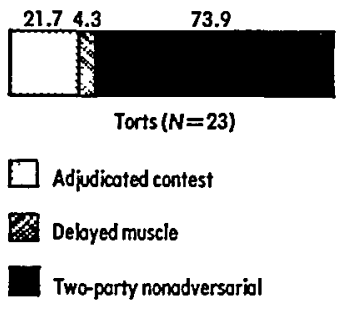

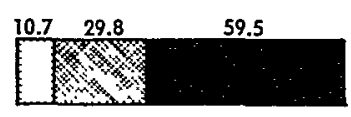

Contracts $(N=131)$

Significance $<0.001$

Cromer's $V=0.208$

Fig. 6. Types of processing for three case types (as percentages)

a) Nature of parties $\square \square$ In section I we saw that different configurations of business and individual parties were associated with tort, contract, and family cases, and it was suggested that each case type involved different forms of social relationships. As figure 7 suggests, different party configurations are also associated with different modes of case processing for tort and contract cases (family cases are omitted because they all involved individual vs. individual party configurations).

Although the number of tort cases is too small to draw meaningful conclusions about the interplay between the nature of parties and case processing, in contract cases there was a relatively strong association between variation in party configuration and variation in the mode of case processing. For contract cases, the most extreme differences were between those involving individual plaintiffs versus individual defendants and those involving business plaintiffs versus individual defendants. When individuals sued individuals, adjudicated contests were most frequent $(40.0 \%)$ and delayed muscle least frequent $(13.3 \%)$. On the other hand, when businesses sued individuals, adjudicated contests were extremely rare $(4.9 \%)$ and delayed muscle was fre- 

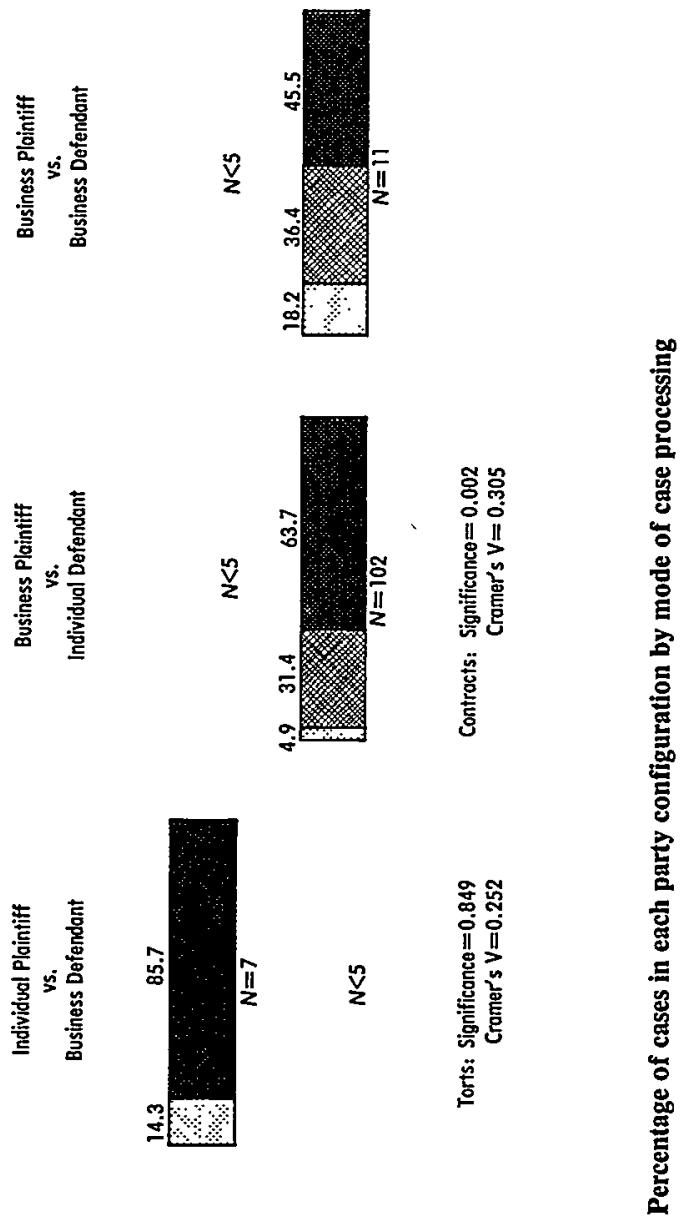

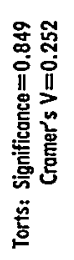

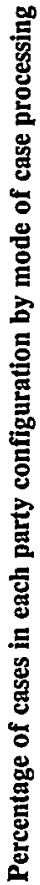
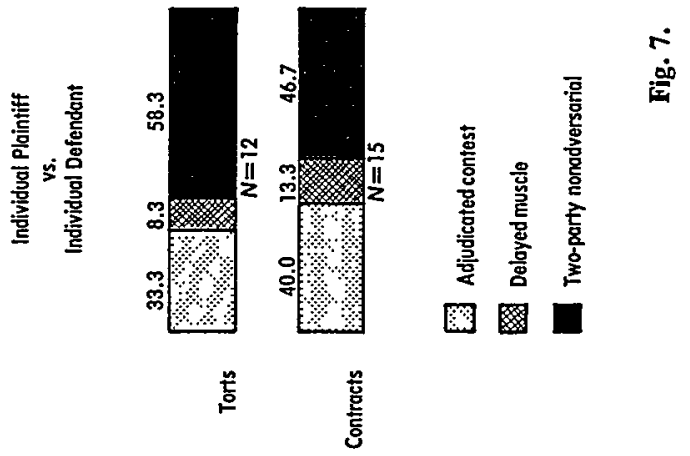
quent $(31.4 \%)$. Thus individual defendants fairly often resisted litigation brought by other individuals but almost never did so when sued by businesses. On the other hand, business plaintiffs relatively often used contract litigation to apply delayed muscle to individual defendants, whereas individual plaintiffs did so relatively seldom.

Both findings suggest that two basically different kinds of contract litigation were occurring within the two party configurations: one involving lively disputed cases between two actively engaged individual adversaries, the other (far more numerous) involving hard-to-collect consumer accounts from defendants who may have been avoiding confrontation or even contact with the plaintiff or who may have been impossible to locate. ${ }^{26}$ Thus, even within a single case type (contracts), cases sort themselves into different patterns based on differences in the underlying social relationships.

Comparisons between contract and tort cases can be no more than tentative, but it appears that in situations where individuals sued individuals, contract cases were relatively high in adjudicated contests while tort cases were relatively high in two-party nonadversarial processing. Generally speaking, however, for both contract and tort actions, cases involving individual plaintiffs against individual defendants were comparatively fertile ground for adversarial confrontation and adjudication.

b) Representation by counsel $\square \square$ The presence or absence of attorneys was strongly associated with mode of processing in torts and contracts cases (fig. 8). For both torts and contracts, cases in which both parties were represented had adjudicated contests more often than when one or both parties was unrepresented. The absence of lawyers was for the most part associated

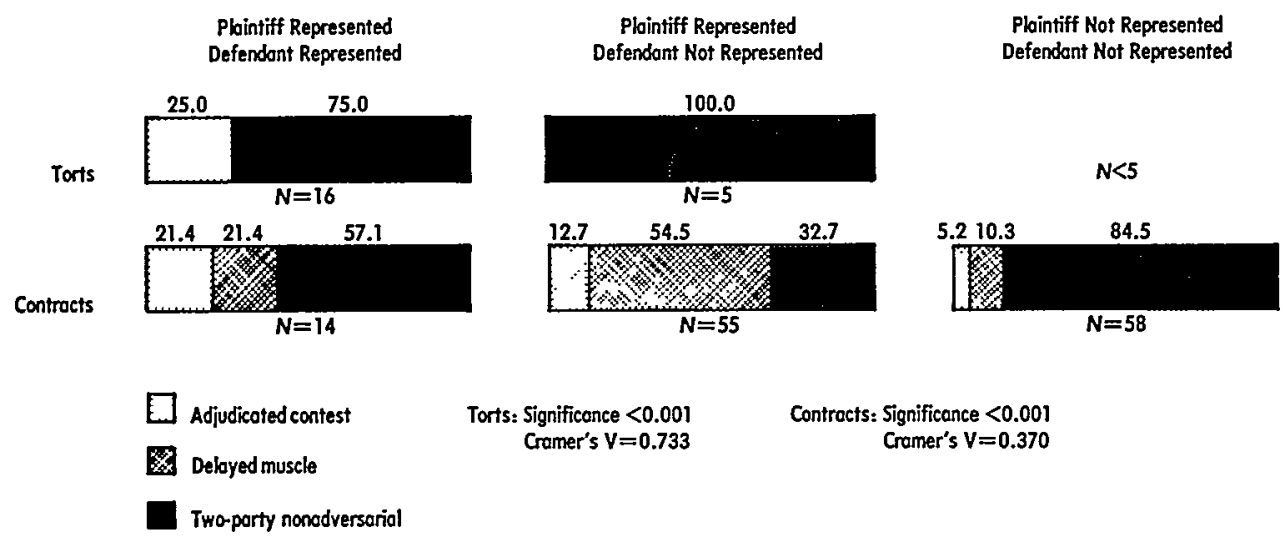

Fig. 8. Percentage of cases in each representation configuration by mode of case processing. (There were no cases in the sample in which defendant was represented by counsel but plaintiff was not represented.)

26. As Jacob observes, "Garnishments were an effective way to contact debtors when all other methods failed. When their wages were withheld, most debtors contacted creditors and made new arrangements to pay their debts." Herbert Jacob, Debtors in Court: The Consumption of Government Services 100 (Chicago: Rand McNally \& Co., 1969). 
with higher frequencies of nonadversarial processing, although in contracts cases the absence of counsel for defendant but not plaintiff was actually associated with reduced frequencies of nonadversarial processing but greatly increased frequencies of delayed muscle. Delayed muscle was relatively infrequent when plaintiff was unrepresented. Plaintiffs usually preferred to have a lawyer involved if supplementary enforcement procedures became necessary, even when they had not used one in the earlier stages of adjudication.

Generally speaking, in torts and contracts cases the presence of two lawyers correlated with higher frequencies of adjudicated contest while the presence of one lawyer or no lawyers correlated with higher frequencies of delayed muscle and nonadversarial processing. As we shall see, however, these findings should not be interpreted to mean that lawyers were agents of adversariness and that the parties if unrepresented would have preferred conciliatory processes. Indeed the opposite may be true. Rather, it would be safer at this point to draw the obvious inference that for cases headed in the direction of a full-fledged trial, the parties recognized the necessity of protecting themselves by hiring an attorney.

c) Amount sought $\square \square$ The third factor to be considered in relation to mode of case processing is the amount sought by the plaintiff. One might expect that when greater sums of money were at stake, the parties would avoid all-or-none adjudicative procedures and would seek less risky nonadversarial approaches by which both sides would be left with at least something. As figure 9 suggests, this may have been true for tort cases but it was not necessarily true for contract cases. In tort cases there were lower frequencies of adjudicated contests and higher frequencies of nonadversarial processing for cases involving larger dollar amounts. In contracts cases, however, a contrary pattern is suggested. Adjudicated contests were more frequent and nonadversarial processing less frequent for cases involving larger dollar amounts. Delayed muscle was also more frequent when larger amounts were sought by plaintiff.

These findings lend themselves to at least two interpretations. First, they might mean that size of claim is positively related to nonadversarial processes

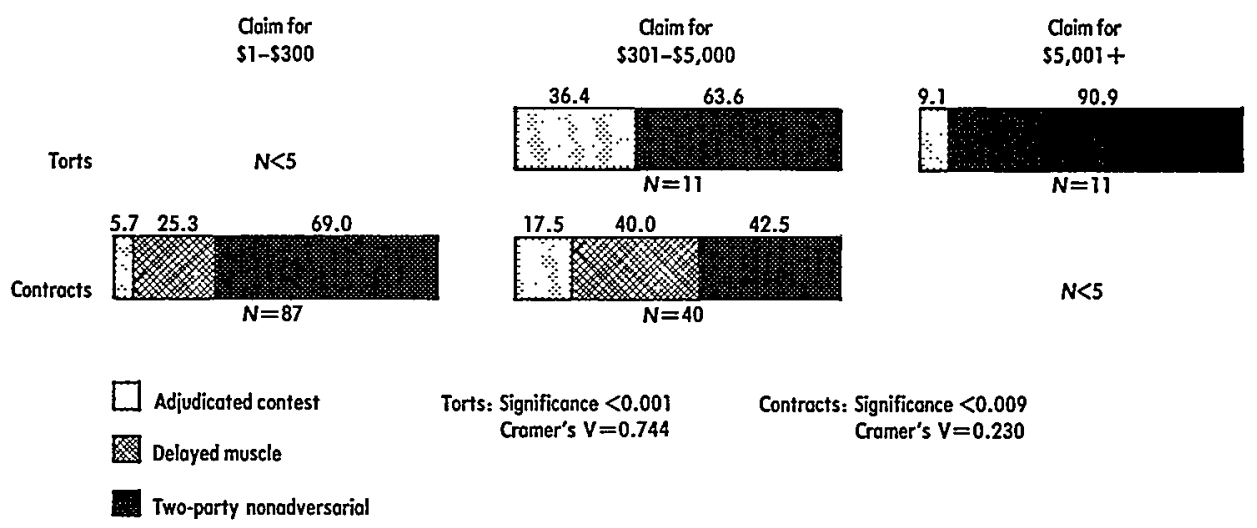

Fig. 9. Percentage of cases in each dollar range by mode of processing 
in tort cases but not in contract cases-an anomalous result that would in itself demand further examination. Second, the findings could be read as mutually consistent rather than inconsistent. Both torts and contracts contained statistically meaningful numbers of cases in only two of the three possible dollar ranges, and they overlapped only in the middle dollar range. Thus, we know the distribution for contract (but not tort) cases at the $\$ 1-\$ 300$ range, and we have the distribution for tort (but not contract) cases at the $\$ 5,001+$ range. It may be that these dollar amounts operated in some absolute way on the processing of cases within the different case types and that if we could fill the two empty (or almost empty) cells for tort and contract cases we would find roughly similar patterns of case processing within the same dollar levels. Given the existing data, however, it is impossible to select one interpretation over the other.

\section{Outcome}

We turn now from examining the processes by which civil cases were handled to examining the outcomes obtained. Once again we find that tort, contract, and family cases follow quite different patterns. We shall consider these different patterns and then explore the relationship between outcomes and other variables associated with the parties and the manner in which their cases were handled.

Civil cases litigated in the Sander County Court seldom resulted in outcomes explicitly favorable to defendants. The vast majority of outcomes were either favorable to plaintiff (or petitioner) or represented agreements of some kind between the two parties. The full range of outcomes is presented in table 3.

For purposes of analysis, this list of possible outcomes will be compressed into three primary categories: outcomes explicitly favoring plaintiff, outcomes explicitly favoring defendant, and outcomes representing agreement

TABLE 3

Outcomes for All Civil Cases

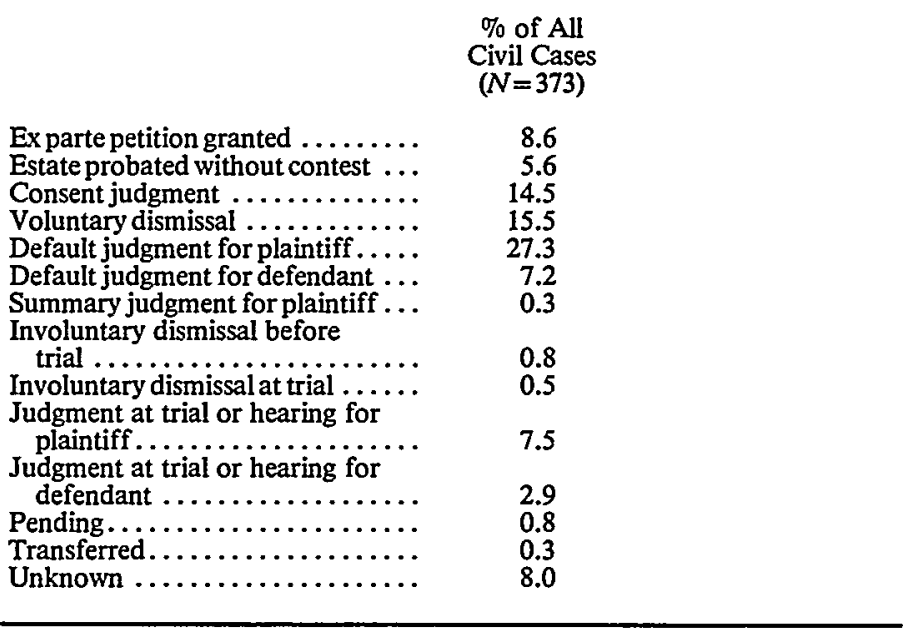


between the parties. ${ }^{27}$ The resulting case outcome variable is, of course, a simplification of reality, for elements of bargaining might well be found in verdicts that formally favor one party or the other. And likewise outcomes that take the form of an agreement may in fact represent a total victory for one of the two parties. In working with docket materials of this kind, however, such simplifying assumptions are helpful in identifying general patterns that might otherwise remain hidden. Table 4 displays in this compressed form the distribution of cases with known outcomes.

Figure 10 displays these case outcomes as they are distributed among the three primary case types. It reveals that plaintiffs did best in contract cases and worst in tort cases. Agreed outcomes were by far the most frequent in tort cases and were least frequent in contract cases. Family cases here, as elsewhere, appear to represent a middle pattern between torts and contracts, but it should be noted that outcomes in family cases are somewhat distorted by this form of analysis. In most cases with outcomes nominally favorable to the defendant, the husband initially filed for divorce and the wife as defendant filed a counterclaim that also requested the granting of a divorce. Almost invariably in such cases the judge would award the divorce to the wife, leading

TABLE 4

Three Major Categories of Case Outcomes

\begin{tabular}{|c|c|}
\hline & $\begin{array}{c}\% \text { of All } \\
\text { Civil Cases } \\
(N=339)^{a}\end{array}$ \\
\hline $\begin{array}{l}\text { Outcome for plaintiff. } \ldots \ldots \ldots \ldots \ldots \\
\text { Outcome for defendant } \ldots \ldots \ldots \ldots \ldots \\
\text { Agreed outcome } \ldots \ldots \ldots \ldots \ldots \ldots \ldots\end{array}$ & $\begin{array}{l}54.3 \\
12.7 \\
33.0\end{array}$ \\
\hline
\end{tabular}

aExcludes unknown outcomes and cases pending or transferred.

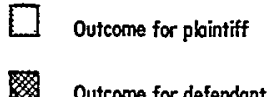

Agreed outcome

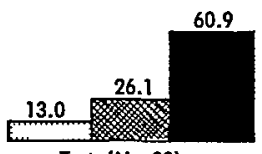

Torts $(N=23)$

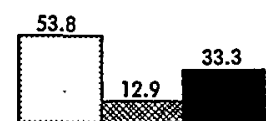

Controcts $(N=132)$

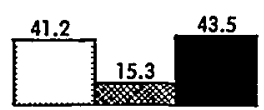

Fomily $(\mathrm{N}=85)$

Significance $=0.007$

Cramer's $V=0.172$

Fig. 10. Ontcomes for three case types as percentages (two-party cases only)

27. The three primary categories of case outcomes in table 4 are derived from the longer list of more specific case outcomes in table 3: (1) "outcome for plaintiff"' includes ex parte petition granted, estate probated without contest, default judgment for plaintiff, summary judgment for plaintiff, and judgment at trial or hearing for plaintiff; (2) "outcome for defendant" includes default judgment for defendant, involuntary dismissal before trial, involuntary dismissal at trial, and judgment at trial or hearing for defendant; and (3) "agreed outcome" includes consent judgment and voluntary dismissal. 
in the formal sense to an "outcome for defendant." In general terms, however, the outcome was the same as that sought from the outset by plaintiff, that is, dissolution of the marriage. The formal classification of such family cases as defendant "victories" reflects only the possibility that the terms of the property settlement and support payments favored the defendant more than would have been the case had the divorce been awarded to the plaintiff.

What was it that caused cases to come out as they did in the Sander County Court? Four factors extrinsic to the system of formal legal doctrine itself had a particularly significant relationship to case outcomes: party configuration, representation, party location, and nature of processing.

a) Nature of parties $\square \square$ The configuration of individual and business plaintiffs and defendants in tort and contract cases is moderately to strongly associated with the outcomes in those cases. Only for contract cases, however, does the sample size permit statistically valid inferences from the data. Interestingly, the data for contract cases suggest that litigants who were individuals were less prone to reach agreed outcomes than litigants that were businesses. One might expect individuals to be more inclined toward conciliatory outcomes; in fact they were more often involved in cases with all-or-none dispositions. This finding corresponds to the earlier finding concerning case processing, in which it was suggested that at least for contract cases business litigants were more often involved in nonadversarial procedures or delayed muscle than were individual litigants.

Figure 11 shows that when both parties were individuals, plaintiffs won $66.7 \%$ of the contract cases and agreements occurred in only $26.7 \%$. By contrast, when both parties were businesses, plaintiffs won outright only $45.5 \%$ of the cases and agreements occurred in $54.5 \%$. An intermediate configuration was the most frequent in contract cases: business plaintiffs against individual defendants. This configuration, which included many debt collection cases, is most commonly depicted in the literature in terms of business organizations extracting payments from relatively helpless consumers with the aid of the judicial system. ${ }^{28}$ Yet even here we find fewer plaintiff victories $(53.4 \%)$, more defendant victories $(14.6 \%)$, and more agreed outcomes $(32.0 \%)$ than in the cases where both parties were individuals.

It should be noted that this pattern held true for tort as well as contract cases, although we cannot be certain to what degree the patterns in tort cases were caused by chance. ${ }^{29}$ Thus although plaintiffs did very well in the Sander County Court and although agreed outcomes were also quite common, differences among the various party configurations suggest that plaintiffs did

28. See, e.g., Note, The Persecution and Intimidation of the Low-Income Litigant as Performed by the Small Claims Court in California, 21 Stan. L. Rev. 1657 (1969); David Caplovitz, The Poor Pay More: Consumer Practices of Low-Income Families (New York: Free Press, 1967); Wanner, supra note 24; Federal Trade Commission, Economic Report on Installment Credit and Retail Sales Practices of District of Columbia Retailers (Washington, D.C.: Government Printing Office, 1968).

29. It should be emphasized that "agreed outcome" in this section is not equivalent to "two-party nonadversarial processing" in the preceding section. The former refers to outcomes, while the latter refers to the process by which outcomes were obtained. Thus, e.g., adversarial processing (classified as "adjudicated contest" in the preceding section) might result in a consent judgment (classified as "agreed outcome" in this section). 

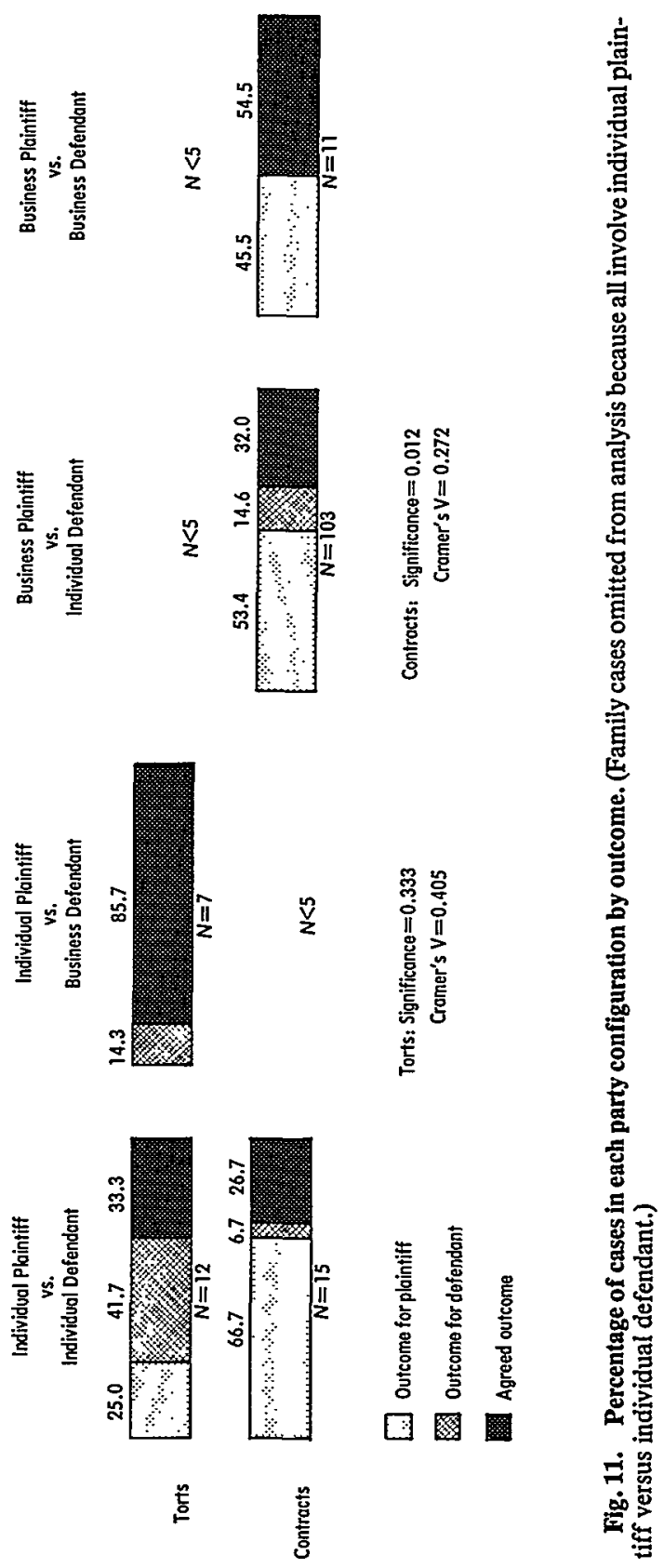
relatively better when individual litigants were involved and agreed outcomes were relatively more common when business litigants were involved. The meaning of these differences remains to be explored.

b) Representation of parties $\square \square$ The representation (or nonrepresentation) of plaintiff and defendant by counsel was strongly related to the outcomes of civil cases. As might be expected, there was a positive correlation between favorable outcomes and representation by counsel. There was also some evidence that the presence of lawyers correlated positively with agreed outcomes (fig. 12).

Figure 12 permits comparisons between three different patterns of lawyer participation: both parties represented by counsel $(A)$, one party represented by counsel (an asymmetrical or unequal configuration) $(B)$, and neither party represented by counsel (C). Looking at configuration $B$, it is clear that here inequality in representation was associated with higher levels of plaintiff victories. Thus if we compare cases in which both parties were represented (configuration $A$ ) to cases in which plaintiff alone was represented (configuration $B),{ }^{30}$ we find in all three case types a strikingly higher percentage of plaintiff victories when there was inequality in representation ( $B$ cases). We see a correspondingly lower percentage of defendant victories for tort and family $B$ cases but, intriguingly, not for contract $B$ cases, in which defendants actually won slightly more often without lawyers than with them. The absence of a defense attorney in cases with represented plaintiffs was also associated with lower percentages of agreements in contract and family cases but not in torts. That is, agreements were more frequent in contract and family cases when

A

Plointiff Represented

Defendont Represented

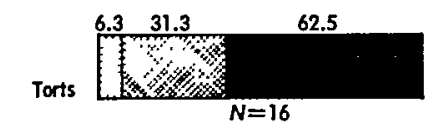

71.4

Controcts

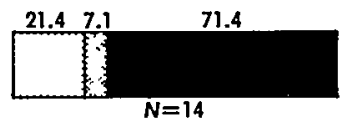

68.8

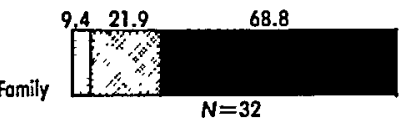

B

Plointiff Represented

Defendant Not Represented
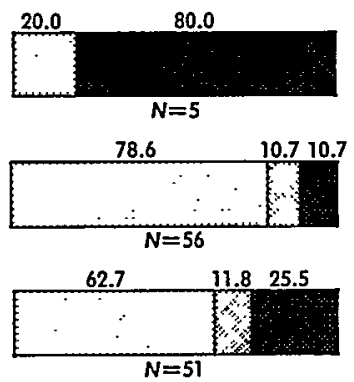

C

Plaintiff Not Represented

Defendant Not Represented

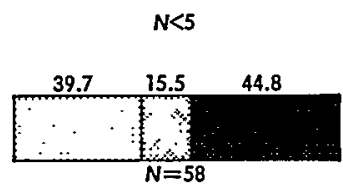

$N<5$

Fomily: Significance $<0.001$

Cromer's V $=0.391$

\footnotetext{
Outcome for plaintiff

Outcome for defendant

Agreed outcome
}

Torts: Significance $=0.061$

Cromer's $V=0.511$

Contracts: Significonce $<0.001$

Cromer's V $=0.353$

Fig. 12. Percentage of cases in each representation configuration by outcome. (For all three case types there were fewer than five cases in which defendant was represented by counsel but plaintiff was not represented.)

30. Cases involving represented defendants and unrepresented plaintiffs are not considered here because such cases were too few in number to permit comparisons of this kind. 
two lawyers were available to work them out than when plaintiff retained a lawyer but defendant did not. This is most dramatically apparent in contract cases, where $71.4 \%$ of the $A$ cases had agreed outcomes but only $10.7 \%$ of the $B$ cases did.

Figure 12 also permits comparisons between two different kinds of equality in representation: cases in which both parties retained a lawyer (configuration $A$ ) and cases in which neither party retained a lawyer (configuration $C$ ). In such a comparison the significance of lawyer involvement should be particularly apparent. ${ }^{31}$ Only contract cases provide cell sizes large enough to permit such comparisons. In that case type, plaintiffs did distinctly better in $C$ cases than in $A$ cases, but so did defendants. Victories for both plaintiffs and defendants in $C$ cases (both parties unrepresented) were more frequent because agreed outcomes occurred much less often than in the $A$ cases where both parties retained lawyers. This analysis suggests that the presence or $a b-$ sence of lawyers was related to outcomes in two different ways: (1) when representation was unequal (specifically when plaintiff but not defendant had a lawyer), outcomes tended to favor the party with a lawyer and agreed outcomes were relatively less common for contract and family cases (but not for tort cases); and (2) when representation was equal, in contract cases at least, the two represented parties were far more likely to reach an agreed outcome than were two parties without lawyers. The implication is that the presence of lawyers on both sides creates a situation where bargaining and negotiation are likely to occur. To this extent the presence of lawyers was associated not with increased adversariness but with increased negotiation and settlement.

c) Party distance $\square \square$ The data from this study suggest that outcomes in civil cases are also related to the locations of the parties at the time of litigation. Because of the heavy concentration of plaintiffs and defendants in Sander County, it was difficult to test the importance of party location for outcomes in all different case types. The only statistically significant findings were for the location of defendants in contract cases. Although the location of plaintiffs in these cases is not considered, it should be noted that $87.8 \%$ of the plaintiffs in contract cases resided in Sander County.

Figure 13 suggests that the more distant the defendant was from Sander County, the more likely it was that the plaintiff would obtain a favorable disposition. Distance also appeared to inhibit negotiated settlements. As the defendant's distance increased, there was a decrease in the frequency of agreed outcomes, although the frequency of agreements when defendants were located in nearby " $N$ " County was about the same as when defendants were located in other Illinois counties. Generally speaking, then, the significant distinction for agreed outcomes was between defendants located in Sander County (higher probability of agreement) and defendants located anywhere else (lower probability of agreement).

31. Comparisons of this kind are obviously limited in the sense that the cases in each of the representation configurations may not be equivalent. The decisions of plaintiffs and defendants about when to hire lawyers may be based in part on the strengths or weaknesses of their cases. Thus, differences in outcomes among the various representation configurations may result as much from intrinsic differences in the cases themselves as they do from the influence of lawyer involvement. 
The location of the defendant did not bear any important relationship to the chances of obtaining an outcome favorable to defendant in contract cases. Defendants in "N" County actually won slightly more contracts cases than defendants in Sander County, although defendants elsewhere in Illinois did not. The variation was small and no significant pattern was apparent.

In sum, although plaintiff's likelihood of a favorable outcome improved with the distance of the defendant, the defendant's odds for a favorable outcome were not greatly affected either positively or negatively by distance. However, defendant's distance was associated with lower frequencies of agreed outcomes. This is not surprising in light of the diminished opportunities for communication and negotiation when the two parties were far apart. To this extent, the association found between distance and outcome corresponds with common sense.

d) Nature of processing $\square \square$ The ways in which civil cases were processed correlated strongly with the outcomes obtained. For purposes of this analysis, all cases were categorized either as processed without trial or processed with trial. The analysis was confined to tort and contract cases, because only four family cases in the sample went to trial. ${ }^{32}$

Figure 14 shows that both plaintiffs and defendants had a greater chance of obtaining a favorable outcome in cases that were tried, but this was because of the elimination after a trial of the middle ground of agreed outcomes. Thus, while both parties' chances of winning increased in cases that were tried, so did their chances of losing.

Generally speaking, however, when cases went to trial defendants' chances of winning improved more markedly than did plaintiffs' chances. Indeed, in tort cases defendants' chances of winning a favorable outcome at trial were more than seven times greater than their chances of obtaining a favorable outcome with no trial. This striking statistic is no doubt a product of the hostility of local juries toward tort plaintiffs. To a much lesser degree, however, the same pattern is reflected in contract cases. The most obvious explanation for this pattern in contract as well as tort cases is that defendants were most likely to "hang tough" when their case was strongest. Thus the group of
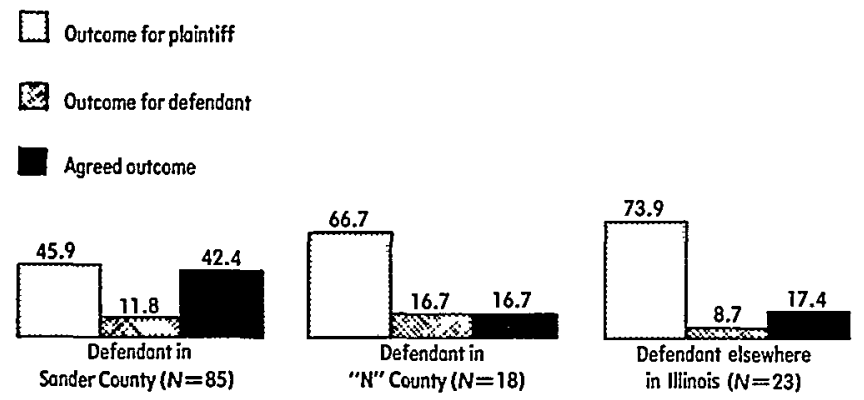

Significonce $=0.009$

Cromer's $V=0.257$

Fig. 13. Outcomes in contract cases by defendant location (as percentages)

32. Once again, it should be remembered that sealed family cases were not included in the analysis. 
cases that went to trial, as compared to cases processed without trial, probably contained more strong defendant cases to begin with, and the outcomes may simply reflect these intrinsic differences in the cases themselves. Of course, plaintiffs with strong cases would also be expected to hang tough, but there is a difference. Defendants, since they do not initiate civil lawsuits and are often reluctant participants in litigation, usually lack the plaintiff's capacity to screen out weak cases before the complaint is filed except when they have an opportunity to make an acceptable settlement. Thus, one would expect more defendants than plaintiffs to be associated with weak or untenable cases. Figure 14 suggests that many such defendant cases are winnowed out in the no-trial cases through plaintiff victories and agreed outcomes. The remaining cases that go to trial would thus reflect a relative improvement in defendants' chances of winning as compared to the improvement in plaintiffs' chances. It would seem that this is the product of a screening process operative in the earlier stages of the litigation process.

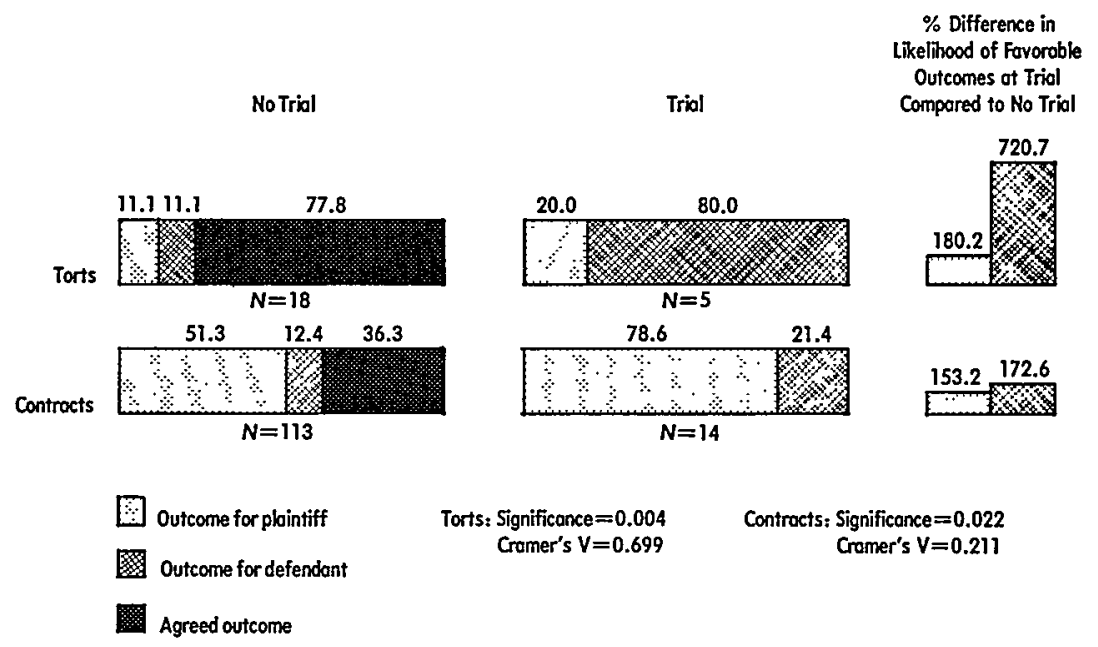

Fig. 14. Percentage of cases tried and not tried by outcome. (Family cases omitted from analysis because only four went to trial.)

\section{Summary of Process and Outcome in the Court}

In this section I have attempted to show that tort, contract, and family cases in the Sander County Court were processed and resolved in rather different ways. There were common features, of course, such as the general avoidance of trials, the general prevalence of nonadversarial procedures, and the general tendency for plaintiffs to win outright victories or to come away with a negotiated settlement rather than a defeat. Nevertheless, each case type had its own distinctive profile, and this was not surprising in light of the finding in section I that tort, contract, and family cases grew out of fundamentally different kinds of social relationships. Such differences exerted their influence in matters relating to process and outcome as well as in matters relating to cases and parties. The relationship of process and outcome to 
variables such as party configuration, representation by counsel, amount at stake, and party location is not surprising. Each of these independent variables represents in its own way a facet of the underlying social relationships and interactions that give rise to civil cases. By identifying the importance of such variables in the shaping of process and outcome, I do not pretend to unlock any secrets that will explain why civil cases were handled as they were in the Sander County Court. What is unlocked is a door that leads from the courthouse back into the community itself. Explanations for the handling of civil cases in the court are to be found in the social order from which the cases and parties emerge. We turn now from an examination of process and outcome in the court to an exploration of processes and outcomes for civil cases in the community as a whole.

\section{B. Process and Outcome in the Community}

\section{Torts}

Analysis of the civil docket of the Sander County Court suggested that torts were litigated relatively infrequently, that they were processed by adjudicated contests somewhat more often than the other case types (although the dominant mode of judicial processing was still negotiation), that plaintiffs fared considerably worse in tort litigation than in the other case types, and that defendants in tort cases did extremely well when the cases went to trial.

This distinctive litigation profile is quite consistent with what we have already learned about values and attitudes concerning injuries in the county and factors opposing the aggressive assertion of rights in this area of law. In the earlier inquiry into the community context of tort litigation (sec. I), I focused on problem perception and the emergence (or nonemergence) of actual cases in various social settings. In this section I will examine the modes of processing such problems and conflicts and will explore the kinds of outcomes associated with different forms of processing.

a) Nonjudicial processes and their implications $\square \square$ As we have already seen, the dominant mode of processing for injury cases in Sander Countyand the form of processing most consistent with local attitudes toward this type of problem-was to allow the matter to lapse without any active assertion that one's interests had been violated. Often this would occur simply because the injured person failed to perceive the event as one involving a wrongdoer and a victim, although even if such a perception should occur, there were still many factors at work that inhibited any forceful assertion of interests by the injured party. The implications of this mode of processing are clear-losses were not shifted from the injured party to the party responsible for the injury. They were absorbed by injured persons or their insurance companies. The various purposes of tort law were not well served by this state of affairs. Not only was compensation not provided, but there was no effort by individuals or by the judicial system to control behavior detrimental to the public. In this type of procedure there was only one kind of outcome possible-potential tort defendants escaped liability. Such outcomes, viewed 
in aggregate terms, suggest a society in which unlucky individuals subsidized the injurious activities of persons or enterprises who acted without proper regard for the safety of the community.

A number of community observers mentioned two-party negotiation as another possible mode of handling personal injury cases in the community. In cases like the hypothetical personal injury (see 819 supra) used in this study, for example, parents of the injured child might contact the company directly to inform them of the hazard with the primary purpose of making it safe for others. Fewer parents would ask the company to pay compensation for the injuries. It was not entirely clear how local companies dealt with such requests if made. On the one hand, many observers described local companies as being highly responsible in such matters, although "responsibility" in this context may well refer to a readiness to abate the hazard rather than to pay compensation for losses. On the other hand, everyone in the community was aware of the local value system concerning personal injuries and the poor record of personal injury plaintiffs in the local court. Thus it is difficult to imagine that potential defendants in such cases, if they were initially approached informally by the unrepresented injured party, would make anything more than a minimal offer of compensation, since they would know that if the matter should go to litigation their position would be very strong. If the claim were against a business enterprise outside Sander County, other factors would reduce the likelihood that direct two-party negotiation would often yield favorable results to the injured party. Not only would formidable strategic problems arise in dealing with an enterprise located far from Sander County, but large and distant organizations would likely respond to claims for compensation by requiring elaborate claims processing that typically would involve attorneys on both sides. That is, simple two-party negotiation under such circumstances would probably be transformed into something else, something more complex and formal, before the possibility of extrajudicial compensation could even be considered.

Community observers also mentioned that some injured persons would routinely seek compensation from their own insurance company. Although this mode of case processing involved negotiation, it did not necessarily imply any form of contact with the party that caused the injury. Rather than frame the event in terms of the liability of the "wrongdoer," claimants would be inclined to handle the losses through health and accident protection they had provided for themselves, thus conforming to local values emphasizing self-reliance in dealing with injuries. (Of course, insurance companies, having paid such claims, might then be able to sue as subrogees, but even actions of this kind were not often brought in Sander County.) Local industrial workers, according to union and management officials, were fairly aggressive in seeking workers' compensation for job-related injuries. In fact, a union steward described many of the claims of his fellow union members as "unbelievable." On the whole, however, local residents were not particularly aggressive, even in dealing with their own insurance company. In part this was because they were usually familiar with the local insurance adjuster. In 
part, too, it was because the adjuster made a point of handling claims as swiftly as possible to allay anxieties about receiving compensation and to forestall the intervention of friends, relatives, or attorneys who might have grander ideas about who should pay and how much should be provided. ${ }^{33}$

Occasionally the insurance company would recognize the liability of its own insured to the injured party and would pay compensation even when it had not been requested:

Now we have some people that have had their kid injured on our insured's property, and they were not our insured. And we call up and offer to pay their bills because our insured has called and said, "My kid Tommy cracked that kid over the head with a shovel and they hauled him off to the hospital." And I called the people and say, "We have medical coverage," and they are absolutely floored, some of them, that it never crossed their minds. They were just going to turn it in to their own . . . health insurance, and not do anything about it whatsoever, especially if [Tommy's parents] are close friends. . . . A lot of people would just turn it in on their own medical insurance and then just leave 'em be, and not bat an eye.

The major local insurance company was rarely involved in litigation of any kind. It was estimated that in automobile cases, which are usually the most fertile source of tort litigation, fewer than 10 cases involving the company had been litigated in the past 15 years. These estimates conformed to findings in the docket analysis concerning the infrequency of tort litigation as well as the infrequency of trials for all civil cases.

The insurance adjuster suggested several reasons why judicial procedures so rarely came into play in cases involving injuries to persons or property. First, she cited the local value system opposing the assertion of such claims. Second, she mentioned the importance of fast and highly personalized adjustment of claims by the local insurance company. Third, she emphasized the reluctance of local attorneys to involve themselves with tort actions, which reinforces our earlier picture of noninvolvement by Sander County attorneys in tort cases that were actually litigated. In part she explained this reluctance in terms of the adherence by local attorneys to community norms opposing the assertion of tort claims. But the insurance adjuster also emphasized their general unfamiliarity with this area of law and their innocence in the ways of insurance companies in particular. This was true not only of local attorneys but of attorneys everywhere:

Most attorneys don't know beans about car accidents and insurance. I'll let you in on our whole secret if you don't know it already (laughs). . . . I think that doing business on car accidents is probably the lowest priority of any training that you have.

Discussions with judges and attorneys substantiated much of what this insurance adjuster said. Only a few local attorneys handled any significant number of tort cases. Most cases, it was agreed, were handled by insurance companies without the involvement of lawyers. As one attorney observed:

33. See supra discussion at 821-22. 
The adjusters can move quicker in a rural community. They get out there faster. And the time that lawyers usually see an accident case is one, if you got this deal in Chicago where they're chasing them, which just doesn't happen out here. Or if the adjuster has done something to offend the person that's collecting. And if they haven't done that, if they get out and move reasonably quick, acted reasonably polite, the case gets settled. It never sees a lawyer.

Furthermore, he said, 'in Sander County there's not over three lawyers that are competent to handle an accident case. Five lawyers max." Handling of such matters by insurance adjusters without the involvement of attorneys was not, however, necessarily seen as a good thing. Another attorney argued that "insurance companies take advantage of those people, having settled for what looks like a big settlement and really. it isn't."

b) Lawyers and injury claims $\square \square$ Even when people suffering personal injury or property damage did see a lawyer, their claims were usually settled without filing a civil complaint. Two local attorneys estimated that this occurred $75-80 \%$ of the time:

In a small town like this when you know all the lawyers, or even if the lawyer's from " $N$ " County, we know most of the lawyers there, if we know the other party's got counsel, why the first thing we'll do is call up and say, "Can't this thing be settled?"

Another local attorney emphasized that client attitudes also pushed cases toward negotiated settlements without filing suit: "A lot of people are more conducive to settlement here just because they're attempting to be fair as opposed to making a fast buck." At the same time, he observed that settlements often involved medical expenses only, without compensation for pain and suffering or other forms of damages. Thus it is not clear why he viewed such settlements as more "fair" than a larger damage award. Since he was one of the few local attorneys who did handle a significant number of tort claims, his comments serve as a reminder that attorney involvement did not necessarily inject a more expansive view of the appropriate range of recovery for an injured person in Sander County.

The local bench and bar understood and sometimes complained about the local attitudes opposing large damage awards in tort cases, but by their words and actions they also endorsed such attitudes, whether consciously or unconsciously, and drew on them in handling injury cases. A local judge praised out-of-court settlements in personal injury cases as a reflection of "the maturity of the lawyers and insurance companies and aided by the liberal discovery rules." Yet he knew well that such settlements were for very low amounts, and he knew as well that discovery after the filing of a lawsuit was almost never used in Sander County. That is, settlements were being obtained without any real development of the facts and issues at stake. His observation that "the people are largely more happy" with this form of case processing and this kind of outcome was, as we have seen, only partially substantiated by the comments of the tort litigants interviewed, some of whom felt that their recovery was far too low.

Lawsuits were filed by attorneys, then, in only a small fraction of the tort 
claims they handled, and, of course, such claims were themselves quite few in number. When complaints were actually filed, no elaborate pretrial discovery took place as a prelude to settlement. Yet it was also obvious that in most cases the attorney who filed would not expect the case to go to trial. Trials were so infrequent and so unsuccessful from a plaintiff's point of view, that most plaintiff's attorneys would anticipate that a filing in the Sander County Court would lead to a negotiated outcome, even without the aid of discovery procedures. The filing itself, then, was usually intended as no more than a stimulus to begin negotiating in earnest. As another attorney observed:

[Filing a complaint] shows you if you're serious, it wakes up an adjuster or an insurance company, many of whom are dilatory and don't really believe that and really won't make any serious effort to settle a case until a complaint is on file. Most good personal injury lawyers will, if they see that it can't be negotiated or settled rather quickly, . . . get the complaint on file, and I believe that serves a purpose of bringing about negotiations to a greater degree than before the complaint was filed.

The same attorney also observed that filing a complaint can be a way of ensuring that the plaintiff's lawyer will deal with a lawyer on the other side and, as was suggested by the docket analysis, the negotiating process was considerably more likely to result in settlement when both parties were represented by counsel than when only one side was represented:

You're either talking with an adjuster or about that time they see you're serious and have to get an answer on file so then an attorney comes into the picture. I would rather deal with attorneys on the settlement of the cases than I would with insurance adjusters.

c) Impact of litigation on patterns of case processing and problem perception $\square \square$ In tort cases, whether they were handled judicially or nonjudicially, outcomes fed back into the case processing itself and affected strategic choices of the parties as well as basic perceptions of the underlying events. We have seen in the docket analysis that plaintiffs in tort cases had less success in the Sander County Court than plaintiffs in any other type of lawsuit, and pushing their claim to the point of formal trial and adjudication served their adversary's interests far better than their own. Local juries, everyone agreed, were strongly sympathetic to defendants in tort cases and were very unlikely to return a verdict satisfactory to plaintiff. The juries were composed of the most traditional and conservative elements in the community and reflected a deep distrust of claims for compensation in injury cases.

The likelihood of prodefendant outcomes in cases that went to trial contributed to some of the most distinctive characteristics of tort law in Sander County. (1) It symbolically reinforced the local value system that opposed such claims and thereby discouraged even the initial perception of injuries as anything more than "accidents." (2) For injuries that were perceived as an invasion of legal rights, prodefendant outcomes at the trial level discouraged the assertion of claims for compensation even through nonjudicial channels. 
(3) When such claims were made through nonjudicial two-party or threeparty processes, respondents had little incentive to make generous settlements, since everyone knew that the claimant lacked leverage and that a threat to "see you in court" was essentially worthless. (4) Persons inclined to challenge awards by insurance companies would be similarly discouraged from doing so, since no local forum was available in which such challenges were likely to be viewed with favor. (5) Attorneys were strongly disinclined to file tort actions in the Sander County Court. Negotiated settlements were the preferred mode of procedure, and the filing of a complaint was at most viewed as a tactic in such negotiations. Whenever possible, tort actions were filed in other counties where plaintiffs fared better than they did in Sander County. (6) The filing of a tort action in the Sander County Court may, in some cases at least, have served plaintiff's purposes by stimulating negotiations and bringing lawyers into the process on both sides. At the same time, however, litigation served defendant's purposes by bringing the matter to a forum where outcomes tended to favor defendants. In tort actions in which a complaint was filed, far more than in other types of litigation, defendants were well advised to hang tough, to adopt an inflexible bargaining stance, and to let the plaintiff worry about what might happen if the case went to trial. It is probable that firm defendant bargaining strategies accounted for the fact that, proportionately, almost twice as many tort cases went to trial after the filing of a complaint as did contract cases on a percentage basis. In this sense, too, outcomes influenced process.

\section{Contracts}

The docket analysis suggested that processes and outcomes in contract cases differed substantially from those in tort cases. Investigation of the social context of contract litigation in Sander County reinforces that suggestion. Contracts, as we have seen, were handled by a higher frequency of delayed muscle than either torts or family cases. This form of processing, perhaps more than any other, suggests the use of the court primarily as an extension of the collection process rather than as a forum selected to decide the merits of a case. It should be emphasized that such an expectation concerning the role of the court was the reverse of the role the court played in tort cases, where everyone knew that if a settlement could not be reached the court would skeptically probe plaintiffs' claims rather than routinely enforce them. Contract litigation also quite often led to nonadversarial settlements (59.5\% of contract cases), but proportionately fewer contract cases were resolved in this manner than were tort and family cases. Unlike tort cases, outcomes in contract cases were generally favorable to plaintiffs or suggested an agreement had been reached between the parties. Defendants seldom won. By and large, litigation in contract cases was a process very congenial to those who brought such actions.

a) Nonjudicial processes and their implications $\square \square$ Litigation was not the only procedure by which contract claims could be successfully asserted in Sander County. Because such claims were viewed sympathetically through- 
out the community, nonjudicial processes also were quite effective. Among these, three approaches to contract problems were most often mentioned by community observers. The first was self-help. One observer, a minister, commenting on the case in which the individual failed to pay the full $\$ 100 \mathrm{debt}$, observed "there are some average people that would punch the guy right in the nose." Other observers agreed, including one person who recalled that he had witnessed a fist fight involving an unpaid debt for a construction job which, although small, occurred in the winter when work was scarce and the money was needed. Other observers felt that the violence would be directed at the fence that had not been fully paid for, and one farmer recalled that a local roofer once threatened to tear down a recently installed roof when his customer refused to pay for it. It was only after he put the ladder in position and prepared to destroy the work he had just completed that the customer agreed to pay the bill.

When the process was some form of self-help, outcomes did not usually compensate claimants for the lost value of their time and materials. Frustrated creditors did, however, obtain instant vindication and gratification in situations where they saw no feasible way to force the debtor to pay a small bill. Self-help "helped" but only indirectly. Like any form of vigilante activity, it provided a means for the more powerful to impose outcomes on the weaker party, and these outcomes were typically punitive or destructive rather than compensatory. Such procedures seemed to draw on strong community sentiments in favor of the underlying claim. Indeed, they provided a symbolic affirmation of local values concerning the sanctity of contractual agreements and thereby reinforced the local normative structure. Moreover, as the stories of such incidents were told and retold in the community, they served as a general deterrent to similar breaches.

A second nonjudicial mode of processing for such claims was gossip. As one observer commented: "He'd tell everybody and his brother that he met about that blankety-blank guy that was supposed to pay me $\$ 100$ and only paid me $\$ 75$." In part, this was a way of letting off steam, but gossip also served a function similar to self-help. It punished parties who breached by labeling them in the community as people who could not be trusted to keep their word, and the consequences could be quite harmful: "The word might get out enough that he would find out that nobody would work for him anymore." Most observers had seen this kind of thing occur in Sander County and agreed that it was a very common way of handling such problems. One observer, for example, described a gathering place for local contractors where gossip was exchanged not only for pleasure but as a matter of professional interest:

I hear those things all the time. I do. I'll tell you where I hear them. I stop in a smoke shop in the morning for coffee at every opportunity. Kind of starts the day out. And you do hear that, you know. And there's contractors in there. And they had a bad experience with this one and that one. And it's never litigated. They're out $\$ 25$ and they know next time that they're gonna do it differently.

While some observers believed that gossip played a positive role in main- 
taining community norms and imposing sanctions on wrongful behavior, others felt that it was an irresponsible and unjust way to handle this kind of problem. One school official, for example, while admitting that "it happens all the time, all the time," went on to observe:

I'm not a big fan of gossip so I don't think it serves much of a positive purpose. It seems to me it just serves to have people feed on their own inadequacies. . . . By the time it gets to the third friend, the truth has been masked completely, because they probably don't get it from the original source and it becomes no longer fact. It becomes rumor and it gets twisted ... It makes people who don't even know other people antagonistic toward some of those people because of what they heard. There are people in this community who like me and don't like me and have never met me. The same thing happens to my board president, and to my teachers. It just depends on what they've heard. Now I know that happens. It's not something you'll ever stop. It doesn't mean I have to like it.

Gossip in matters of this kind depended on two things. First, to use gossip successfully, there had to be a shared set of norms so that it would be obvious to everyone that contract breachers had done something seriously wrong. Without widespread agreement concerning the wrongfulness of the act, the gossip would lose its effectiveness and might even prove harmful to the people who set it in motion. Second, the people who sought to use gossip in such cases had to be sufficiently integrated into the community to have a network of friends and acquaintances to whom they could tell the story. They had to know where to find an audience, and they themselves had to be sufficiently known to their audience to have credibility and to generate sympathy. Thus gossip as a procedure for handling contractual breaches in Sander County was useful primarily to persons with a place in the local community, who shared widespread community values and attitudes. As such, it was a powerful instrument for preserving the established order.

Most community observers believed that the aggrieved party in such matters would attempt to contact the other party directly to ask why payment had not been made in full and to persuade him or her to pay the amount outstanding. Depending on the original reason for the partial default, this mode of case processing might, or might not, yield results favorable to the complainant. Its significance for the handling of the case was that unlike gossip it opened a channel of direct communication between the two principals, so that grievances and responses could be heard and discussed by the individuals actually involved. This meant not only that the problem could be brought more sharply into focus through the disputants' give-and-take but also that the matter could be dealt with in a relatively private and self-contained manner. Unless one of the parties simultaneously engaged in gossip, the outside world need not become aware of or involved in the problem.

What did this process imply regarding outcomes? On the one hand, the potential defendant was faced with neither the punitive features of self-help and gossip nor the coercive features of litigation. On the other hand, any two-party configuration is susceptible to certain problems, among them the 
possibility of even greater domination by the stronger of the two parties. Outcomes based on power differentials and unilaterally imposed norms are especially likely when only the two parties at interest are engaged in efforts at conflict resolution. This possibility was suggested, for example, in an interesting case involving nonpayment of a telephone bill recounted by the telephone company official:

I had a beautiful little lady, probably some 65,70 years old, not too long ago she came in. She said, "My brother has lived with me. He's done this. I never had trouble," she told me. I know that what she was telling me was true. And she said, "I'm afraid to be without [my telephone]." And I said, "You just got to live without it until we get it paid for. So if you pay it up, then I'll put it back in." I said, "You know me and I know you. If you hold good and you make good and if you got any trouble, you come and tell me about your problems so I know what the problem is. And you just pay me out of your social security check what you can. And when we get it paid up, then I'll put it back in." We carried that on, it took us almost 14 months, she and I, to get that account paid up. But, you see, it was simply because we communicated. I knew and trusted her. I didn't leave the telephone service there. I didn't let it go ahead and become the noose that she couldn't handle. But she was not irate at me for disconnecting the phone. I was not irate at her for having gotten into the problem. We both had a solution.

The product of two-party negotiations in this case was an outcome that both parties agreed to and, at least from the viewpoint of the narrator, it was an outcome that was more or less acceptable to both sides. Yet the terms of the settlement forced an elderly woman to live without a telephone for more than a year, despite her own apprehension concerning the danger of such an arrangement and despite the fact that her brother, and not she, was apparently responsible for the payment problem. Although the outcome may have seemed satisfactory at the time to both parties, an outsider is struck by the degree to which the terms appear to favor one side to the detriment and apparent risk of the other. As Vilhelm Aubert observed, two-party negotiations tend to be subjective, an "I-thou" encounter in which external objective norms are less likely to influence perceptions or determine outcomes than in situations where a third party is present. ${ }^{34}$ The potential for unfair outcomes reflecting party power disparities is very great.

Interestingly, the local bill collector viewed part of his work not as twoparty negotiation with debtors but as mediation between debtor and creditor in which he acted as the third party rather than as an immediate party at interest:

We hear both sides because once the dispute comes up we go right back to the original and say, "Hey, we've only heard one side now, and we're not privileged to what actually happened according to you. What do you say about this?" "Yeah, he did come back and say this was defective or something." I say, "Why didn't you adjust it then?" "Well, he was so mad and so hostile, I

34. Vilhelm Aubert, Competition and Dissensus: Two Types of Conflict and of Conflict Resolution, 7 J. Conflict Resolution 26 (1963). 
just told him, you know, send you a bill, and you pay it and don't ever come back." No wonder the guy don't pay when you handle it like that. . . . I guess counseling, it comes in here even though we don't set out for it to happen, it does come in and in most cases I think if you talked with people in a given tone, talked to them like, you know, like the individuals they are, why, they respond. They respond pretty well in most cases.

The possibility of a collection agency acting as a mediator between debtor and creditor provides a fascinating twist to traditional images of the collection process. To some extent, the collector may indeed have transmitted claims and counterclaims back and forth between the two original disputants. But the collector, too, had a stake in the resolution of such matters, and his interest was clearly on the side of seeing that payment was ultimately made. Compare, for example, the following statements by the same collector, which cast more than a little doubt on his neutrality and objectivity as a "third party":

When you get to sitting here and you look at the thousands of dollars that you're trying to effect collection on and you know that there's a great percentage of them you'll never get and no one will get, it's gotta bother you. It's gotta bother you. . . . I say [to the debtor] "This is not the most serious thing that's going to happen to you, but you should make arrangements to try to get the bill paid. Why haven't you paid it? You know, we get to the bottom of it, why haven't you paid it?"

The collection agency heard countercomplaints by debtors to the same extent that the creditor itself considered the debtor's responses to collection efforts. The collector did not really act as a mediator, of course, nor did anyone actually expect him to. His willingness to listen to the debtor's side of the story was simply an aspect of the two-party negotiations in which he engaged, and for the most part the collection agency stood in the place of the creditor and not midway between the disputants.

b) The use of litigation for enforcing contract claims $\square \square$ When twoparty negotiations failed, nonjudicial approaches were often abandoned in favor of litigation. As we have seen, litigation in contract cases was viewed as a natural extension of the collection process and was not subject to the same kind of disapproval associated with the litigation of tort actions. Typically, what was sought and expected was not so much a judicial consideration of the merits of the case as a stimulus for the other side to begin serious discussions on how to pay the debt. In the following description by the local collector, it can be seen how nonjudicial approaches flowed naturally into judicial approaches, leading to the typical outcome of an informal settlement:

We've got a lot of married couples here who incur bills where the . . . men are not aware that these bills are even there and ... the wife for a year or better has been able to ward off any collection activity. But when the sheriff comes down and serves that complaint, it's a different ball game. They start to get a little bit nervous about it. And I have had calls relative to, " $\mathrm{My}$ wife told me today that we may have to go to court on this." And I say, "Well, you probably better talk to my attorney because that's where we're at at this point." . . . The man will say, "Well what brought this all on?". . . And 
I'll explain to him, "Well, we've had this account. We have billed you. We have called." "Well, you have never talked with me." I said, "Probably not, but there again, the bill exists and this is the way it was incurred. If you want copies of them, why, come in here, I'll show you exactly where the bill existed, and what do you intend to do about it?" "Well, I want to pay it." I say, "Fine. Well, if you'll pay it, why we'll, you know, you get it paid and we'll instruct our attorney to dismiss the case. All we want is the money. We don't want to go to court or anything, we just want to get the thing resolved."

While filing a civil complaint in a collection case made a settlement considerably more likely, it did not guarantee that negotiations would take place in every instance. Indeed, total nonparticipation by the defendant in a collection case occurred quite often, and $46.1 \%$ of all contract cases resulted in default judgments for plaintiff. Such cases involved circumstances in which the defendant's whereabouts could not be determined or where the defendant simply failed to appear in court. Adjudication did not bring debtor and creditor together in those cases, but it did provide the creditor with a judgment that allowed him or her to pursue the matter in a different (and more coercive) way. If the creditor could find assets of the defendant that could be attached or an employer whose wage payments to defendant could be garnished, then the judgment could be satisfied even without any informal agreement between the parties through the exercise of delayed muscle. The director of the local collection agency stated that it was his assumption whenever he obtained a default judgment that further enforcement steps would be necessary and indeed such steps were often required even when the defendant was present in the courtroom at the time the verdict was rendered. Supplementary enforcement of judgments was usually thought to require a lawyer's expertise, so many contract cases that had been handled by plaintiff pro se to the point of judgment saw lawyers enter the picture later to set in motion the machinery to attach assets or deduct wages.

Litigation of contract claims also led on occasion to formal adjudication on the merits, but as we have seen (supra at fig. 6) this occurred only in about one case in every ten. Plaintiffs did quite well in cases that were actually tried and saw at least one advantage to the adversarial mode of processing: it brought the defendant physically into the courtroom. The local collector felt that the defendant's presence in court greatly increased the likelihood that he or she would pay the judgment without lengthy and sometimes futile supplementary enforcement activity:

They will pay it . . . it's a different atmosphere for him right before a judge.

The respect is there and there would be a lot of people who will say they don't owe a bill and they'll say they won't pay the bill, but the time comes when they're up in front of a judge, they change their minds because they realize that this has gone too far.

The defendant's presence in the courtroom also enhanced the possibility of negotiation and settlement "in the corridors," a process that the judge encouraged, in part by impressing the defendant with his or her power and authority:

It's a completely different atmosphere from what they're accustomed to, and 
it's not at all like what they see on TV, and they are not sitting in an armchair eating popcorn. They're standing before a judge, and the judge is asking them direct questions, and he expects direct answers from them, and they respond alike. They say, "Yes, I owe the bill." And they may say, "I owe the bill, but I don't want to pay it," or "I don't feel I owe all of it because of this." And then he will say to them, "Why don't you sit down and talk with these people." We wish to pass on this case for awhile, and we sit down and a lot of times we're able to iron things out.

The collection agency was familiar with the judicial process and in fact had structured its activities from the outset mindful of the possibility of litigation as a tactic to collect its bills. The defendant, on the other hand, was in a new, unfamiliar, and intimidating setting. It is true that he or she, by participating in the proceedings, was able to make certain arguments or counterclaims. Indeed, the small claims court procedures in Illinois were designed to accommodate individual defendants without requiring them to hire lawyers. Yet personal observation of proceedings in Sander County revealed that several of the judges had no patience with "informal" presentations in small claims actions and would accept only a lawyerly style of argumentation, which the unrepresented parties were incapable of providing. And even when judges were willing to hear a more folksy and less legalistic presentation, it was rare for defendants to make much headway in arguing a case that had been structured from the beginning to facilitate litigation by the creditor to collect the debt. The distinctive small claims court procedures, even when they were administered with great sensitivity and fairness, were of little significance to the defendant because they were merely the end point of a long process that had been controlled and structured primarily by the creditor. In this process, formal legal doctrine concerning debtors and creditors played an important role, yet the perception and application of doctrine was greatly affected by the nature of the parties, the relationship between them, and the differences in their capacity to understand and implement legal rules and forms.

c) Impact of litigation on patterns of case processing and problem perception $\square \square$ Outcomes in litigated contract cases, unlike outcomes in tort cases, favored plaintiffs by awarding them outright victories in a large percentage of the cases and by facilitating negotiation and settlement in most of the others. Seldom were contract defendants able to defeat the claims of their creditors entirely. This pattern of judicial outcomes affected nonjudicial procedures and outcomes as well. First, it symbolically reinforced local values favoring strict adherence to contractual obligations. Thus, the kind of breach presented to community observers for discussion was described by some of them, particularly by farmers, as simply unthinkable-they could not imagine it occurring. The more typical pattern of behavior, at least among people embedded in the traditional network of social relationships, was illustrated by the statement of a Sander County farmer:

We have a small business. People buy meat from us to eat. They buy a steer from us and have it slaughtered, and so on. We've done this for 20 years, and I have never lost one dime. I have never had one person not pay me, and I've had several of them went bankrupt, and so on and so forth. I really don't pay 
any attention to bookkeeping or what. I mean, if someone owes me, they owe me. And you know, I've never sent anybody a bill or anything. I mean, sooner or later they all pay.

The symbolic reinforcement of local values also meant that gossip and rumor could operate more effectively since, as we have seen, they depended on a widely shared set of norms. Furthermore, two-party negotiations between debtors and creditors were unquestionably influenced by the shared knowledge that litigation was a real possibility and that the creditor's claim would be likely to meet with great success in court. Favorable outcomes in collection actions also had certain unintended effects: unlisted telephone numbers in Sander County were becoming more numerous, often in an attempt to frustrate contacts by creditors. Increased mobility in the community, the tendency to pick up stakes and move quickly without leaving a forwarding address, may also have had some relationship to the collection process. It provided debtors with one of the few successful ways to defeat a creditor's collection efforts-by removing oneself from the reach of judicial or nonjudicial processes.

Despite their generally successful use of litigation to enforce contractual claims, business creditors did not necessarily believe that they were the fortunate beneficiaries of a legal and social system arranged in their favor. On the contrary, many business people expressed outrage and even despair over the difficulties they confronted in a society that they viewed as biased toward the consumer:

There is no law to protect business. There is no law in this country that is going to protect a businessman. It protects the consumer, but it doesn't protect me. If you buy on credit from me, there's nothing I can do if you don't pay. You stop and think about that and take a look at the way the laws are. Everything for the consumer. I'm not protected. Even though I had to put the money out to get the product that he's buying, that he wants. He doesn't have to buy it. And he wants my credit, he wants me to put the money up so he can use it. And when he gets all through and he don't pay his bill, he walks away and walks away scot free. What are you gonna get out of the court from him? They don't put you in debtor's prison. He just walks away. He hasn't got money, he says. "I don't have it." What are you gonna do? Nothing. You take the loss. So it really, it's all one-sided justice.

These sentiments were widely held among members of a business community who, unlike the traditional farming community, dealt every day with individuals outside the old-time, close-knit society of Sander County. They seemed to express dismay at the breakdown of traditional systems of social control, including the use of informal power, prestige, and gossip and unhappiness with the role of legal doctrine, which they perceived as hastening social decay and disorder. Judicial enforcement, they were well aware, was useful to the extent that it served as an extension of nonjudicial procedures for enforcing contractual obligations. But standing alone, litigation too had its limitations, and these business people encountered its limitations every time one of their debtors evaded judicial enforcement measures or declared bankruptcy, a step the business people found even more frustrating and un- 
fair. The telephone company official, speaking of an apparent increase in personal bankruptcy filings, said "basically it has become a dodge" and found the trend disturbing because "you've got a lot of creditors who are going to be hurt."

The world as seen by these business people was quite different from the world as seen by the farmer who had a small meat business on the side. Contractual breaches were not only imaginable, they were a fact of life and they tormented the business people because they meant lost earnings and because they blatantly offended traditional Sander County values. Increasingly, business people said, they were forced to deal with the problem not by relying on judicial or nonjudicial enforcement processes but by restructuring the underlying transaction itself. According to most of the business people interviewed, the terms on which credit was extended had been tightened considerably and confined to a relatively small number of customers who were known to be good risks. The relationship between credit practices and judicial procedures was quite direct. As one businessman said: "We have used the courts less and less for small matters because we have tightened up more and more at the time of sale." Thus the pattern of outcomes from judicial and nonjudicial processes, together with the evolving framework of formal legal doctrine, at least as they were perceived by the business community of Sander County, had influenced the basic relationship between businesses and consumers and had changed the nature of the interaction between people in the community from one based on trust and shared norms and values to one based more on strict control by businesses over all commercial exchanges.

\section{Family}

In this section, as in the sections on torts and contracts, I shall examine the judicial and nonjudicial processes for handling family cases in Sander County and the outcomes with which such processes are associated. It will be recalled that family cases, particularly divorce cases (which accounted for nearly three-fourths of all family cases in the Sander County Court) were characterized in the docket analysis by a pattern of processing that involved twoparty nonadversarial proceedings more often and trials less often than either of the other two case types (see figs. 5 and 6). Outcomes often were determined by agreement of the parties, although a substantial number of divorce cases also resulted in a default judgment for plaintiff. Such cases appear in the docket as total victories for plaintiff, although in fact they were frequently the product of informal out-of-court agreements. Finally, in the docket analysis some cases appeared to result in outcomes for defendant. These cases, as already noted, were usually divorce actions filed by the husband. When the wife filed a countercomplaint that also requested a divorce, the judge usually granted the divorce to the wife, thus awarding "victory" to the defendant.

a) Nonjudicial processes and their implications $\square \square$ We turn now, as in the discussion of tort and contract cases, to a consideration of nonjudicial as well as judicial processes and outcomes for marital problems in Sander County. We saw in the earlier discussion of family cases that what was once 
the most usual way of handling unhappy marriages-lumping - had become a far less common and socially expected way of dealing with such problems. It still occurred, but the community observers concurred in describing a process by which lumping fairly readily transformed itself into less passive forms of problem response. Nearly all community observers agreed that the presence of a young child would have little effect in keeping together an unhappy and unloving marriage. Many of them contrasted this with the situation in times past when a couple would stay together until the children were grown. On the other hand, money-or the lack of it-was often mentioned as an extremely important factor in preserving marriages. As a social service worker observed of her low-income clients:

They'll stay together forever as long as he brings home the food and there's no violence and there's no alcoholic, there's no abuse. . . . I had a client who remarried, she was a divorcee and she remarried a man, and I didn't think he took care of her children at all very good. He ignored them. He didn't take care of her very good. And she said to me, "He takes us out for fish every Friday night, he doesn't beat me and he doesn't drink." She was happy. . . . That met her needs. . . . To a lot of people that's okay. That's where they're at, and they're comfortable at that.

She emphasized that even though local norms had become more permissive concerning the dissolution of a loveless relationship, women with no money and no place to go may be inclined to stay rather than strike out on their own. Lack of money was not an absolute deterrent to divorce, as was obvious from the frequency with which lower-income as well as middle- and upper-income couples obtained divorces in Sander County. Nonetheless to understand lumping as a mode of case processing, it is necessary to take account of the constraints imposed by financial considerations.

Community observers also noted the significance of extramarital relationships. It was one thing to endure a marriage in which husband and wife felt less intimate and loving than they once were. It was quite another thing to learn that one's spouse was having an affair. At this point, observers said, lumping was often abandoned and active steps were taken to end the marriage.

Consultation with a third party, judging from descriptions offered by community observers, seldom amounted to actual mediation. Typically third parties were not go-betweens or advisers to both sides but rather sympathetic listeners who occasionally offered suggestions to one of the parties. The following statement by a hairdresser, for example, suggests a process in which a wife vents her frustrations and is then encouraged to resume lumping:

You wouldn't believe the stuff they tell you, stuff, you know, that I wouldn't even think of telling anybody else. . . . [It's] almost like therapy. They should give us some psychology training along with hairdressing, I think. . . . They'll say, "Oh, I'm so glad I got that off my chest. I can go home now, and I don't have to worry so much about it. But don't you tell anybody."

Friends and other confidants did not always encourage lumping. 
Sometimes by their very example, they encouraged troubled married persons to break out of an unhappy relationship and start fresh:

The people are available [for advice] that they know and trust and have known them for a long time. But they don't do that. If they get any pure counseling, it's from people who are having the same kinds of problems. Or from a guy who's had problems in divorce and they see him having a ball.

Many observers mentioned the powerful influence of divorced or unmarried friends who seemed to be enjoying their independence. Discussions with such third parties were less significant for their substance than for their encouragement by example to those who felt locked into boring or stifling relationships.

One minister, who described himself as an effective marriage counselor, felt that the dream of an exciting and romance-filled life after divorce was the primary fantasy that he had to combat to preserve marriages. For example, referring to one case in particular, he recalled:

One of the marriages we saved, she has a continual struggle with her marriage. She accused me of keeping it going. You know, she kind of had to halfway hope that I would let her off easier, you see. Even though I'm liberal, I wouldn't let her off. On practical grounds, not necessarily religious grounds, I kept saying for practical grounds, "Look it's your family. That's the pipe dream. That's the fantasy out there that you're living. You know, that there's some guy out there waiting for you, and you're 30 years old, and that's just a fantasy.". . . I kept putting the pressure on her in that case, just not as a listening post. In that case, I could see that maybe when she's 50 she'll thank me. Or at least wait until she gets the children grown.

By attacking what he described as adolescent fantasies, this minister focused attention on what he perceived to be practical realities and contrasted the security of marriage, even in an unfulfilling relationship, to the uncertainty of divorce.

Counseling by ministers was usually aimed at preserving marriages, not at removing individuals from relationships that might be psychologically harmful or even physically dangerous. Some ministers stated flatly that they would never recommend a divorce. One fundamentalist minister argued that marital problems, like almost all problems, were a symptom that true religious convictions were absent. Thus his response would never be couched in terms of divorce but rather in terms of straightening out the couple's relationship with God. He observed that the divorce rate among true believers was extremely low.

Because ministers emphasized reconciliation in almost all cases, it was vitally important for their work as marital counselors that they talk with both husband and wife. Yet as we have seen, it was usually difficult for them to do this. Typically the wife would initiate the contact, but the husband would refuse to participate in the counseling beyond one or two sessions at most. For this reason pastoral counseling was often ineffective. And as observed, ministers were further handicapped by their parishioners' reluctance to consult them until their marriage was already seriously deteriorated. Thus the nature 
of the process itself, combined with the individualistic values of the parties involved, militated against the success of pastoral counseling (and "success" was normally defined as preserving the marital relationship).

b) Lawyers and their handling of divorce cases $\square \square$ Lawyers, too, claimed that they often played the role of marriage counselor and attempted to preserve relationships when they were called on to obtain a divorce. Many stated that they always asked their clients if they had seen a minister or a marriage counselor and encouraged them to do so. They would inquire whether there was some chance for reconciliation. One lawyer even scheduled appointments on particular days of the week to discourage hasty decisions to divorce:

Most calls for somebody to see on a divorce or dissolution of marriage come on Monday. I've often thought we'd cut our divorce rate down by eliminating Saturday and Sunday. And the reason being that's when they're together or that's when they may go out to visit the taverns and he looks at another woman or vice versa and they're at home together and they have a chance to fight. So I never set it for them to come in on Monday or Tuesday. I never did that. I would either make it Friday or the following week. And my reason was by Wednesday they had patched it up again.

Despite such statements, however, there was evidence that some lawyers were not very happy with their counseling role or with the often indecisive attitudes of couples contemplating divorce. Indeed the most successful lawyer in Sander County stated flatly that he had lost patience with this entire area of practice:

I don't take divorce. I haven't taken them for years, because most of the time when you get them in there and the point of the dispute is so goddamned trivial that it's disgusting, that's all. . . . My wife was laughing the other day, saying a lot of those couples are still married today that I talked to for years.

Other lawyers were not quite so frank. The lawyer with the largest divorce practice in Sander County said that he put great emphasis on counseling and reconciliation:

When people come in about a divorce, one of the first things I ask them is if they're able to or if they're willing to try reconciliation or marriage counseling. Now we have a doctor in " $N$ " County that is originally from Sander County, and he's a psychiatrist, and he does marriage counseling. And we refer them to him. . . . We talk very seriously about marriage counseling.

Yet some clients of this lawyer did not recall his emphasis on reconciliation or counseling. They were struck on the contrary by the speed and efficiency with which he had been able to file a divorce action:

When I went to file it was so easy. I just went in there (to the lawyer's office) and said, "I want to file for divorce." He says, "What do you want," and I said, " $\$ 50$ a week and the house." And he said, "Okay, go pay the secretary." I was in there about ten minutes. . . . Of course, at the time I thought, "This is great," you know, 'cause that's what I wanted, and he was making it so easy for me. I thought, "Hey, this is all right. This guy's, he's pretty good. You go in and tell him what you want and he gives it to you. No problem." But after 
having been through it, I wouldn't want to have to do it that fast again. I would want to make sure. . . . We had three kids, and he was making it so easy. Not even to mention like to see a counselor or, you know, like you said, try to work things out, or how long has this been going on, or what.

Divorce lawyers were widely and bitterly criticized in Sander County because they were thought to concern themselves too little with the human aspects of the dissolution process and to be too inclined to respond in a routinized and mechanical fashion. This is not to imply that divorce lawyers in the county adhered to a strictly formal legal approach to divorce in the sense of full-fledged adversarial processing and the participation of attorneys on both sides. On the contrary, defendants were unrepresented in fully $63.5 \%$ of all divorce cases. A substantial number of divorce cases in which defendant went unrepresented appeared to involve situations in which both parties consulted the same attorney and worked out an agreement with his or her advice. Indeed litigants sometimes stated that husband and wife had retained a single attorney, that the attorney had represented both of them. Attorneys, of course, were prohibited from representing both sides in a divorce and when interviewed for this study they usually stated that they took great care to make it clear to their clients that they could represent only one of them, since they were (technically at least) in an adversarial relationship with the other. Nonetheless divorce clients did not always perceive the process in those terms, and sometimes came away with the impression that the lawyer had in fact represented both husband and wife. The defendant in one divorce case, for example, said:

I didn't know that she had gone down to see a lawyer. But the reason she didn't go through with it, she said she didn't have the money to pay for it. And he wouldn't represent me for the fact that she came to see him first. But he said that if it was agreed with me and agreed with my ex that he would represent both of us.

When the wife in this case agreed with her husband to use one lawyer, the lawyer arranged a meeting at which both parties were present and a settlement was worked out according to their common wishes:
We went down together and saw him and drew up what she was to get and what I was to get. And I took all my receipts showing that I owned everything before we got married, and he just said that, well, that she couldn't get nothing out of the marriage except for her personal effects. And she wanted the car, and I said, well, she could go ahead and have the car, but if she's late on any payments that I wanted it in there that I had all legal right to go pick it up, because I didn't want to ruin my credit status. And he put it in that way and the court granted it.

The parties also agreed that the wife would nominally appear as plaintiff in the divorce action to be filed in court and, because the law required allegations of fault, that the grounds would be mental cruelty. Nonetheless, the husband and wife and the lawyer clearly viewed the process as a consensual and not an adversarial one. After the meeting, the lawyer drew up the papers 
immediately and drove the husband to the courthouse so that he could be served that same day. On the day of the hearing, the husband sat in the back of the courtroom while his wife testified. In the court records, the outcome in the case is noted as a default judgment for plaintiff.

Unlike the ministers and the other few resources that an unhappy couple might consult in Sander County, lawyers did not direct their efforts primarily at preserving the relationship. Although they were aware in the abstract that this might be socially desirable, their actual handling of divorce cases appeared to be more oriented toward the mechanics of dissolution. None shared the antidivorce sentiments of the ministers. Attorneys were not trained to preserve marriages, and when couples came to them, they acted in the professional capacity that they knew and understood rather than in the role of a marital counselor. That lawyers were often consulted before ministers or counselors (who were oriented toward preserving marriages) tells us as much about changes in local values and social resource use in Sander County as it does about the alleged shortcomings of divorce lawyers.

c) Impact of litigation on patterns of case processing and problem perception $\square \square$ In family cases as in tort and contract cases, the pattern of judicial dispositions affected processes and outcomes at all stages and in all settings in the county, nonjudicial as well as judicial. For example, the relative ease with which divorces could be obtained in court undoubtedly contributed to the decreasing use of most nonjudicial resources in Sander County. Why bother with lengthy, painful, psychologically demanding, and perhaps embarrassing procedures aimed at preserving an unhappy marriage when the alternative of court-sanctioned dissolution had become more accessible and free of stigma than ever before?

Another example of judicial outcomes feeding back into other modes of case processing was the distinctive approach to maintenance and child support in Sander County. Most observers agreed that levels of child support in divorce decrees were low compared to the adjoining counties. But what was perhaps more surprising was that maintenance was almost never granted, even under the old Illinois divorce law prior to 1977. This was explained by the local judge as a regional custom of long standing and one to which he subscribed in principle. As he put it:

I suppose that it is modern times that women and men are pretty well treated equally, and it's not looked upon that a woman once divorced is going to need support forever if she's able and if she is in good health; and it's kind of a social burden on a man, some people feel, to pay for a dead horse.

He believed that obligations between the parties to a divorce should be settled to the maximum extent possible at the time of the divorce and that only child support obligations should continue until the children reached majority. $\mathrm{He}$ assumed that when husband and wife were both capable of working, then the marital property should be divided more or less equally and the husband should be left only with the responsibility of providing roughly $\$ 20-\$ 30$ per week for each child.

Although the judge described automatic waiver of maintenance as a re- 
gional custom, some observers identified it more specifically with his personal philosophy. This was the view of the leading divorce lawyer in the county, who illustrated his point with a case in which the judge barred a woman from maintenance against the wishes of her husband and herself:

We had a case where I represented a 24-year-old boy, George, and his wife was represented by another attorney. And she was 22 and she had asthma. And she really sincerely felt that she might at a later date get sick to the point where she couldn't work. She was not asking for maintenance, but she asked that she be allowed to reserve maintenance. And I talked to George, and he said that he would leave her that. He knew she had asthma, and if she couldn't work he wanted to help her out, because they had two children and, you know, he really felt that sincere about it. He really was willing to. And I told the judge that, both lawyers told the judge that, we wanted the girl to be allowed to reserve maintenance. And the judge here in this county put her on as his own witness, and he asked her questions: how old was she when she developed the asthma, and it was around 12 or 13 . And he brought out the fact that she had this condition before she married him and all that. And in his final order then, even though he knew that the husband would agree to maintenance, he ordered that there would be no maintenance and that she be barred from maintenance.

Whatever the true origin of the local custom opposing maintenance, it was clear that people throughout Sander County were familiar with the policy. Community observers and local attorneys and their clients generally were aware that the court was unlikely to grant maintenance in any divorce action. And indeed maintenance was waived in all 85 divorce cases sampled in the docket analysis. This particular judicial norm was as widely known in the community as any encountered in this study. Undoubtedly it shaped negotiating strategy between the parties to a divorce; and it will be recalled that the terms of most divorce settlements were the product of consensual arrangements between the parties. Possibly, too, it affected other modes of dealing with the problem of the unhappy marriage. As we have seen, women who tolerated and endured unsatisfactory relationships sometimes did so because it offered them financial security. If the local trial court had viewed claims for maintenance with greater sympathy and had viewed the husband's income as a resource that both partners had worked to create and in which both had a legitimate interest, then it is conceivable that many women would have been less inclined to lump their marital problems. They might have felt that divorce would not totally impoverish them and that they would be able to build a happier life by leaving the relationship.

The fact that maintenance was not awarded in the Sander County Court was yet another aspect of the administration of family law that some local people found unsatisfactory. Like the insistence upon fault as an often fictitious ground for divorce, like the charade of formal adversarial processing in cases that were obviously resolved through consensual processes, the denial of maintenance was another factor that jarred some local sensibilities. It made the formal judicial procedures appear unfair and remote from the realities that divorcing couples had to face. Not only did it affect the nature of case processing at all levels in Sander County, it also fed into a broadbased disillusionment with the legal system as a whole. 


\section{CONCLUSTON}

The linkages between the civil trial court of Sander County and its community were various and complex. Yet law and conflict resolution in the court and in the community can be fully understood only in terms of these linkages. Explanations of the role of courts in society have suffered from a failure to examine carefully the interchanges between formal rules, structures, procedures, and outcomes on the one hand and social relationships, values, norms, and processes on the other. Court-focused studies have failed to grasp the richness and importance of the social and cultural setting; community-focused studies have neglected the profound impact of official rules, procedures, and patterns of case disposition. At least in a rough and preliminary fashion, this overview of an empirical study has suggested some of the benefits of focusing directly on the cross-relationships themselves and has outlined some of the insights to be obtained from examining the functions of a civil trial court in the context of the life of its community.

It should be apparent from this study that the social environment of the Sander County Court affected judicial case loads and processes in a number of ways. I have argued, for example, that different case types (tort, contract, and family) are associated with fundamentally different litigation profiles and that these differences are explainable in terms of the dissimilar patterns of social relationships from which the categories of cases emerge. Tort cases usually emerged from injurious interactions between strangers. Most plaintiffs and defendants were individuals, although a substantial minority of defendants (one-third) were businesses. Local values concerning injuries and individual responsibility inhibited claims at every level, and tort litigation in the Sander County Court reflected such values both in the infrequency of tort actions and in the relatively low success rate of tort plaintiffs. Contract cases usually emerged from pre-existing commercial relationships involving goods or services. More than three-fourths of such cases involved business plaintiffs suing individual consumers for noncompliance with the terms of the transaction (usually failure to pay their bill). Local values strongly supported such claims and the court provided only one avenue among many for asserting them. Such cases were numerous in the Sander County Court and were notable for the success rate enjoyed by plaintiffs (although the enforcement of favorable judgments was by no means assured). Family cases usually emerged from what had once been intimate relationships between individuals who now sought to terminate their marriages. Local values had grown tolerant of married couples who wished to dissolve a loveless relationship, and this form of litigation was both frequent and successful in the sense of providing plaintiff what she or he requested. Judicial routines permitted the many consensual divorces in Sander County to circumvent what were then the fault-based requirements of Illinois divorce law, with the tacit encouragement of local judges and lawyers. Indeed, the increasing unwillingness to use nonjudicial resources (such as ministers and marriage counselors) for marital problems was apparently related to the proficiency of lawyers in obtaining divorces quickly and easily for just about anyone who wanted one.

Among these three case types, one may observe different patterns of law- 
yer use and nonuse, different kinds of judicial processes employed, different patterns of outcomes and enforcement. These differences, and others, are best understood when it is recognized that the cases are generated by different realms of social behavior and relationship in the community, that they involve different categories of social actors, and that they invoke different sets of cultural values. Empirical efforts to study civil case loads in the aggregate, without differentiating among the various case types, always seem to founder on these differences. Such aggregate analyses are usually uninformative because they combine different case categories that have little in common besides the fact that the local trial court-a legal "department store"-has jurisdiction over each of them. Attempts to correlate case load variations and social, political, or economic variables are unlikely to be successful unless such variables are targeted directly at one or another of the specific case types.

It is a mistake in studying civil trial courts to assume that fundamental patterns of social relationship and conflict magically become something different-a "case"-when packaged for purposes of judicial administration in discrete and quantifiable units. Although certain important "transformations" do indeed occur in this process, ${ }^{35}$ cases can be understood only in terms of the social fabric from which they emerge and to which they return after judicial processing. Only by investigating aspects of the society itself-its structure, its values, its people, its politics-can we understand the meaning and significance of the different party configurations and litigation profiles of the various case types. There is no short cut. To understand the workings of courts, we must understand the society in which they operate.

Yet the forces that connect court and community are not unidirectional. Influences flow not only from the social environment to the court but in the other direction as well. Traditional legal scholarship has assumed as a matter of faith that formal judicial processes automatically penetrate and reshape the social order. Although this assumption has been undermined by many empirical studies of law and society in recent years, it turns out to be at least partially correct in the case of Sander County-but in rather unexpected ways. Occasionally judicial decision making actually does become widely known in the community and has a direct effect on behavior and attitudes at the local level. For example, the lack of success of personal injury plaintiffs appeared to reinforce negative community attitudes toward personal injury claims and strengthened the positions of those against whom such claims were asserted. Similarly, the unwillingness of the court to award maintenance in family cases seemed to affect the expectations and claims of divorcing spouses and may even have deterred divorce for women who feared they could not survive financially on their own.

35. I have argued elsewhere that such transformations are significant enough to frustrate efforts to compare litigated cases to nonjudicial "disputes" on a one-to-one basis, as if such entities rather than the underlying strata of social relationships were the appropriate subjects of analysis. For a thoughtful discussion of the transformation of disputes, see Lynn Mather \& Barbara Yngvesson, Language, Audience, and the Transformation of Disputes, 15 Law \& Soc'y Rev. 775 (1980-81). 
But besides the impact of adjudicated outcomes on the local community, the court affected the social order in many less obvious ways. The nature of the judicial process-even apart from the outcomes it dispensed-had important implications for indigenous systems of nonjudicial law and conflict resolution. In contract cases (mostly involving debt collection) this was true because court processes fit naturally into the array of alternative enforcement procedures available to creditors in Sander County. The court was simply a "very effective collection tool" that could be used to supplement nonjudicial pressures and strategies otherwise conducive to forcing payment. In tort cases, by contrast, judicial processes were significant in the community because they provided one of the only means of compelling defendants to hear and respond to claims by plaintiffs. Because judicial processes in tort cases represented a dramatic discontinuity with nonjudicial values and approaches, litigation tended to underscore the social alienation of tort plaintiffs and to brand them as outsiders or even as troublemakers in the community. The ultimate effect of litigation in this type of case was therefore a reaffirmation of community norms opposing such claims.

The court affected local systems of law and conflict resolution in yet another way. Formal legal doctrine provided a highly distinctive set of rules and definitions that channeled and reshaped conflict and relationships at all levels of processing. Consider, for example, personal injury cases involving husbands and wives rather than strangers. Illinois law at the time of the study precluded the possibility that one spouse could assert a tort claim against the other ${ }^{36}$ Instead, formal legal doctrine channeled this kind of conflict in a different direction: toward dissolution of marriage rather than the awarding of damages. ${ }^{37}$ All such cases appeared in the Sander County Court, if at all, in the form of divorce actions rather than tort claims. In many other areas, too, the framework of formal law imposed its rules and definitions on persons and interactions in Sander County, opening up some opportunities for asserting claims but foreclosing others.

At a number of levels, then, the Sander County Court had an impact on the community in which it functioned. Its rules, procedures, and outcomes affected local perceptions of problems and relationships as well as the legitimacy of engaging in different forms of conflict. The court reinforced local values and procedures in some areas of law but tended to encourage lumping and the nonuse of alternative resources in other areas. Awareness of the court and its approach to different types of cases affected bargaining

36. At the time of the study, the relevant portion of $\S 1001$ of what was then chapter 68 of the Illinois Revised Statutes read as follows: "neither husband nor wife may sue the other for a tort to the person committed during coverture." In a later amendment, effective in 1981, the statute was revised to permit spouses to sue one another for intentional torts to the person, but not torts of negligence (Ill. Rev. Stat. ch. 40, Ү1001 (Supp. 1982)).

37. Historically, tortlike remedies were sometimes built into divorce decrees in the form of alimony payments that took into account the wrongful conduct of one of the spouses. See Homer H. Clark, Jr., The Law of Domestic Relations in the United States, 442, 446 (St. Paul, Minn.: West Publishing Co., 1968). However, as we have seen, alimony was seldom, if ever, awarded in Sander County, so even a tortlike "damage award" for personal injuries involving husbands and wives in divorce actions was effectively precluded. 
strategies at all levels, both nonjudicial and judicial. And patterns of judicial case processing in family matters, commercial transactions, or accident cases could affect such relationships and interactions in very basic ways.

It would be a mistake to disregard the significance of formal legal rules, procedures, and institutions in any assessment of indigenous systems of legal ordering and conflict resolution. Yet courts and systems of formal law are also products of the society in which they operate and cannot be understood in isolation. We are only beginning to sense the insights that might be obtained from systematic studies of courts combined with extensive ground level investigations of their social environments. It is in the interaction of courts and their social settings that much of our society's legal life is revealed. 